\title{
MORISCOS EXPULSADOS DE GRANADA Y “AVECINDADOS” EN TOLEDO
}

\author{
POR \\ HILARIO RODRÍGUEZ DE GRACIA \\ Profesor de Enseñanza Secundaria \\ “Doquier que estamos Iloramos por España, que, en fin, nacimos en ella \\ $y$ es nuestra patria natural...
}

RESUMEN: La expulsión y reparto por Castilla de miles de moriscos granadinos comenzó en noviembre de 1570. La primera expedición, constituida por 624 personas, llegó a Toledo a finales de dicho mes, siendo entregadas, a partir de los diez años de edad, a ciudadanos para que trabajasen con ellos como una forma de impedir su desamparo. El objetivo principal de esta parte del artículo consiste en analizar el número de cada partida, su procedencia, las penalidades que soportaron en el trayecto y su destino final.

El estudio de sus preferencias laborales y su ubicación en las colaciones parroquiales toledanas es el aspecto principal que trata la otra parte de este trabajo. Para obtener conclusiones se utilizan unos poderes realizados por el escribano público Blas Hurtado en 1587. Allí aparecen identificados más de cuatrocientos hombres con sus nombres, apellidos, profesión y residencia. La información posibilita conocer cuáles eran sus actividades preferentes y en qué partes del plano ciudadano establecieron su residencia.

PALABRAS CLAVES: Moriscos, granadinos, expulsión, toledo, profesiones, poderes notariales

\section{MORISCOS EXPELLED FROM GRANADA AND CURRENTLY RESIDING IN TOLEDO}

ABSTRACT: The expulsion and resettlement in Castile of thousands of Moriscos from Granada began in November 1570. The first expedition, consisting of 624 people, arrived in Toledo at the end of that month, and all of those from the age of ten were handed over to local citizens to work for them as a way to prevent destitution. The main objective of this part of the article is to analyze the number of each expedition, its origins, the hardships people endured on the journey and their final destination.

${ }^{1}$ D. Quijote de la Mancha, parte II, cap. LIV, palabras de Ricote a Sancho. 
Studying their work preferences and their location in the parish districts of Toledo is the main point dealt with in the second part of this article. Conclusions are drawn from the powers of attorney made by notary public Blas Hurtado in 1587 . In them appear more than four hundred men with their names, occupations and residence. The information allows us to know what their preferred activities were and where within the city they established their residence.

KEYWORDS: Granada Moriscos, deportations, Toledo, professions, powers of attorney

$\begin{array}{ll}\text { Recibido/Received } & \text { 02-12-2011 } \\ \text { Aceptado/Accepted } & \text { 03-07-1012 }\end{array}$

A la hora de construir el pasado, esa parte de la memoria colectiva que da respuesta a los problemas que sucedieron hace tiempo, es imprescindible contar con un armazón epistemológico, indagar en unas fuentes primarias y poner imaginación a los razonamientos que surgen de la investigación. ${ }^{2}$ Parte insustituible en esa tarea son los documentos $y$, entre las fuentes heurísticas conservadas, los protocolos notariales presentan numerosas ventajas: posibilitan rehacer la cultura material, abordar aspectos económicos, bucear en los entramados patrimoniales y hereditarios, estudiar las redes materiales, ojear los detalles de la vida cotidiana, etc. ${ }^{3}$ Poseen otras particularidades, como la de posibilitar la seriación, aceptar la crítica sistemática y ofrecer un alto grado de fiabilidad. ${ }^{4}$ Presentan un lado negativo: requieren emplear mucho tiempo en su consulta para obtener conclusiones. $^{5}$

El hilo conductor de este artículo discurre por el ejercicio profesional de dos escribanos, cuyo cometido consistió en dar fe de lo acaecido a personas concretas. Diego Sotelo, el primero, se encargó de efectuar el registro de los exiliados granadinos llegados a Toledo entre los meses de noviembre y diciembre del año 1570. Acreditó con su signo y firma cuántos eran y de dónde procedían. El otro fedatario, llamado Blas Hurtado, extendió tres poderes generales para pleitos a

${ }^{2}$ Contreras, J. 1996. «Métodos y fuentes: el historiador y sus documentos», La investigación en las fuentes documentales de los Archivos: 181-210. Guadalajara: C.A.B. de CLM

3 Actas de las II Jornadas de Metodología Aplicada a las Ciencias Históricas. La documentación notarial y la Historia. Santiago: Universidad, 1984. Le Goff, J. 1989. «Documento/Monumento», Irargi. Revista de Archivística, II: 102-131. Andújar Castillo, F. 2004, «Moriscos y cristianos viejos, desde los protocolos notariales. Vélez Blanco, 1545-1568», La historia del reino de Granada a debate: viejos y nuevos temas: perspectivas de estudio, en Barrios Aguilera, M. y Galán Sánchez, A. (coord.), Madrid: Actas: 329-350.

${ }^{4}$ Beauvalet Boutouyrie, S., Gourdon, V., Ruggiu, F. J. (dir.). 2004. Liens sociaux et actes notariés dans le monde urbain en France et en Europe. Paris : P. U. Paris-Sorbonne. Laffont, J. L. 1991. "Un enjeu pour l'exploitation des actes notariés: la représentativité de l'acte et de la pratique notariale», en Problèmes et méthodes d'analyse historique de l'activité notarié (XVe-XIXe siècles): 69-90.Toulouse: P.U. du Mirail.

${ }^{5}$ El historiador sigue unos inequívocos movimientos: rellena una papeleta en el archivo para consultar unos fondos, recibe el legajo, desata las cuerdas, examina los expedientes, toma notas, repasa las realidades escritas, acopia información, "atomizada e impenetrable hasta ese instante", entra en relación con la esencia de asunto, "sea cierto o no lo que está leyendo", y escribe una secuencia con suposiciones basadas en pruebas. Darton, R. 2003. El coloquio de los lectores: 16. México: FCE. 
requerimiento de varios cientos de moriscos. Ambas fuentes, de contenido extrapolable, recogen diversos trazos para ajustar la radiografía de los granadinos traídos a Toledo, en tanto en cuanto en ese material heurístico hay referencias, nombre, origen, rasgos físicos, composición familiar, parroquia de residencia, así como otros datos útiles para conocer mejor a los moriscos asentados en la ciudad. ${ }^{6}$

\section{POTENCIALES DISIDENTES}

El levantamiento de los moriscos tuvo lugar durante la Navidad del año 1568 en varios puntos de las Alpujarras, con conexiones por la serranía de Ronda y la Axarquía malagueña. ${ }^{7}$ El caudillo del movimiento, Aben Humeya, o Fernando Valor por el nombre castellanizado, mantuvo una resistencia irreductible por medio de un sistema de guerrillas contra las tropas de Felipe II, mandadas primero por el marqués de Mondéjar y con posterioridad por Juan de Austria. ${ }^{8}$ La rendición quedó sellada con unos acuerdos de paz entre Juan de Austria y Aben Aboo, en noviembre de 1570, cuyas condiciones implicaban la expulsión de varios miles de granadinos de su tierra. ${ }^{9}$ La migración se ejecutó en varias fases y con destinos muy dispares, quedando dispersados por diversos puntos de Andalucía Occidental, ${ }^{10}$ Extremadura $^{11}$ y la actual Castilla-La Mancha, ${ }^{12}$ El asentamiento

${ }^{6}$ La amplitud bibliográfica queda recogida en la obra de Bunes Ibarra, M. A. 1983, Los moriscos en el pensamiento histórico: historiografía de un grupo marginado. Madrid: Cátedra; Candau Chacón, M. L. 1998, Moriscos en el espejo del tiempo. Problemas históricos e historiográficos. Huelva. Universidad; y Sánchez Ramos, V. 2009, «Importancia historiográfica de los moriscos granadinos», Anuario de Historia de la Iglesia, 18:325-346. Son menos numerosos los estudios relacionados con los moriscos toledanos. Entre ellos, cabe destacar el de Pedraza, E. 1985. Población morisca en Toledo en la segunda mitad del siglo XVI. Toledo (ejemplar inédito depositado en AMT). Rodríguez de Gracia, H. 1981. "Un censo de moriscos de finales del siglo XVI». Toletvm, XI: 521-542. Sáez, R. 1984. "Los moriscos en el arzobispado de Toledo a finales del siglo XVI» Cuadernos de Historia 3: 161-172; y Magán J.M. y Sánchez González, R. 1993. Moriscos granadinos en la Sagra de Toledo, 1570-1610. Toledo: Caja de Ahorros.

7 Sánchez Ramos, V. 2000. «La guerra de la Alpujarra, 1568-1570», Barrios M. y Peinado, R. (eds.), Historia del Reino de Granada, II: 502-542. Granada: Universidad. Hurtado de Mendoza, D. 1842. Guerra de Granada hecha por el rey D. Felipe II: 42 y ss. Barcelona: Imprenta Juan Oliveres.

${ }^{8}$ Numerosos detalles sobre la rebelión en Domínguez Ortiz, A. y Vincent, B. 1978. Historia de los moriscos. Vida y tragedia de una minoría. Madrid: Revista de Occidente. Fernández Chaves, M. F. y Pérez García, R. M. 2011. «Notas sobre la destrucción de las comunidades moriscas malagueñas y su reconstrucción en la campiña sevillana, 1569-1610». Áreas, Revista Internacional de Ciencias Sociales 30:123.

9 Barrios Aguilera, M. 2000. "El destino de los moriscos vencidos", Historia del Reino de Granada. La época morisca y la repoblación (1502-1630): 583-607. Granada: Universidad.

${ }^{10}$ Aranda Doncel, J. 1984. Los moriscos en tierras de Córdoba. 64-65. Córdoba: C.A.M.P.C. Lapeyre, H. 1986. Geografía de la España morisca. Valencia: Universidad. Los deportados de Almería fueron conducidos en galeras a Sevilla, según informa Cortés Peña, A.L. 1999. «Un consecuencia del exilio: los moriscos granadinos en Sevilla», en Belenguer Cebriá, E. (coord.). Felipe II y el Mediterráneo. Los grupos sociales. II: 537-553. Madrid: SEC. Datos más precisos al respecto en Fernández Chaves-Pérez García. 2011:121-139.

${ }^{11}$ Hernández Bermejo, M.A., Sánchez Rubio R. y Testón Núñez, I. 1995. «Los moriscos de Extremadura», Studia Histórica, Historia Moderna 13: 89-118.

12 Fueron concentrados en núcleos importantes, bien Toledo o Ciudad Real. Sin ser exhaustivos en la bibliografía, la temática es abordada por Santamaría Conde, A. 1981. «Albacete y los moriscos en el siglo XVI: dos expediciones de moriscos de paz», Al-Basit, IX: 39-48; y Gómez Vozmediano, M. F. 2000. Mudéjares y moriscos en el campo de Calatrava: 81, Ciudad Real: Diputación. La llegada de los granadinos permitió a algunos señores de vasallos, como sucedió en Pastrana, activar la industria sedera, García López, A. 2009. Señores, seda y marginación. La 
resultó dificultoso e implicó tensión y nerviosismo, hasta el extremo de provocar un estado de alerta permanente, ambiente que permaneció latente hasta su definitiva expulsión en 1609. Esos temores hicieron de ellos objetos de una particular vigilancia, con el fin de paralizar la posible conformación de una quinta columna de subversivos o el hecho de facilitar información al turco para perpetrar una invasión. ${ }^{13}$

El comportamiento religioso de los desterrados será observado de manera rigurosa al llegar a su destino. ${ }^{14}$ Tenían prohibido hablar en su lengua, las fiestas eran espiadas con mucha atención, al igual que las costumbres alimenticias, quedaban destruidos los libros escritos en alfabeto árabe y refrenado cualquier signo de sincretismo morisco-cristiano. Todas esas medidas iban encaminadas a conseguir una disciplinada evangelización y, al unísono, intentando que olvidaran los rasgos culturales islámicos y perdiesen su identidad. ${ }^{15}$ La activa participación del clero secular, ayudado por los sacristanes, iba a ser decisiva en el proceso de adoctrinamiento, mientras la base normativa, el otro pilar de esa conversión, quedó contenida en las actas sinodales, así como las sanciones pecuniarias por su incumplimiento.

Las autoridades eclesiásticas encontraron diversos escollos durante la primera fase de la aculturación, sobre todo a la hora de erradicar los hábitos de una tradición secular que quedó enmarañada por el impenetrable secretismo con que practicaban sus costumbres. Desde instancias arzobispales se solicitó la cooperación de los eclesiásticos diocesanos, teniendo en consideración que era imprescindible disponer de una información solvente sobre la herencia cultural y los hábitos religiosos recién adquiridos, a fin de conseguir unos resultados más efectivos en el adoctrinamiento. Así se hizo. Para ello fue utilizada una pesquisa confidencial, de ámbito muy limitado, cuyo centro de interés giró en torno a los procedimientos a emplear en su educación religiosa; aparte de que la indagación sirvió de base a un contexto normativo que enfocó con la máxima extensión el adoctrinamiento posterior, una acción que tardó en ponerse en práctica, con unos primeros pasos caracterizados por una relativa parsimonia. Por esas circunstancias, desde el Consejo de la Gobernación de la diócesis toledana se esbozaban algunas actuaciones a corto plazo, antepuestas hasta llevar las recomendaciones más determinantes a la asamblea del clero diocesano presidida por el arzobispo. Las reflexiones sobre aquellas proposiciones permitieron incluir

comunidad morisca de Pastrana. Guadalajara: Aache Ediciones.

13 Cortés Peña, A. L. 1995. «Mudéjares y moriscos granadinos, una visión dialéctica tolerancia-intolerancia», en Barrios Aguilera, M. y Vincent, B. en Granada 1492-1992. Del Reino de Granada al futuro del Mundo Mediterráneo. 97-114. Granada: Universidad.

${ }^{14}$ La idea apriorística de una conversión nominal al cristianismo, sin dejar de observar su fe ancestral, corresponde al retrato de un morisco hereje en secreto, a decir de García Pedraza, A. 1995. «El otro morisco: algunas reflexiones sobre el estudio de la religiosidad morisca a través de los protocolos», Sharq Al-Andalus, 12: 223-234.

${ }^{15}$ El morisco representa el paradigma de la asimilación forzosa a un estilo de vida nuevo, unas veces con la integración y otras accediendo a un mejor estatus social y económico con esfuerzo y tesón. Con ellos hubo una relativa tolerancia antes del año 1555, convertida en intolerancia a partir de 1563, una vez finalizó el concilio de Trento (Sáez, R. 1984: 168-171). Las repercusiones económicas en Benítez Sánchez-Blanco, R. 1999. "La política de Felipe II ante la minoría morisca», en Belenguer Cebriá, E., Felipe II y el Mediterráneo. Los grupos sociales. II: 503536. Madrid: SECC, trata. 
buen número de ellas en las actas del sínodo convocado por el metropolitano Quiroga, allá por el año 1580, y aplicadas con prontitud. ${ }^{16}$

Dentro de las numerosas incertidumbres sobre la actitud y comportamiento religioso de aquellos "naturales de Granada", una de las principales disyuntivas consistió en saber si los nacidos en la sierra durante el levantamiento estaban bautizados y qué nombres usaban. Se presentía que muchos no recibieron esas aguas ni tenían nombres cristianos, ya que no hablaban castellano ni lo entendían, aparte de que sus padres no sabían firmar y cuando lo hacían utilizaban los caracteres árabes. ${ }^{17}$ La jerarquía religiosa consideró fundamental conocer cuántos eran los cristianizados antes y después de la revuelta y con la mira puesta en ese objetivo se ordenaba preparar "una minuta de los moriscos que están en este arçobispado y se sepa por dónde fueron baptizados sus hijos". Aquel recuento iba a utilizarse después como suplemento a las matrículas parroquiales y a los registros vecinales confeccionados a tenor de lo contenido en la pragmática del año $1572^{18}$.

Las conclusiones sinodales contienen varias medidas encaminadas a erradicar las prácticas religiosas heterodoxas de aquellos moriscos, buena parte de ellas celebradas con un sobrado oscurantismo. Uno de los hábitos a extirpar tuvo relación con el rito de amortajar los cadáveres y emplear como sudario las camisas de lienzo nuevo y los almaizares, o lo que es igual, las tocas con que cubrían la cabeza. ${ }^{19}$ Los curas de almas quedaron facultados para suprimir de forma enérgica ese signo de identificación cultural, aunque la tarea requería la implantación de medidas de observación y un seguimiento preciso: "y hallándolos con tales mortajas o almaizares den noticia dello a los vicarios y jueces para los que lo hicieren sean castigados con todo rigor". ${ }^{20}$

${ }^{16}$ La problemática de la asimilación se trató en varios sínodos, Amezcua, M. 1994. "Los sínodos postridentinos en la diócesis de Badajoz", Revista de Estudios Extremeños, 2: 357-391; y Fernández Collado, A. 1996. Concilios toledanos postridentinos: estudio y edición. Toledo: Diputación. La disgregación de la comunidad morisca, desde el punto de vista normativo y sociocultural, y la erradicación de sus creencias, en García López, A. 1995. «Moriscos andalusíes en Pastrana. Las quejas de una minoría marginada de moriscos, con noticias sobre su paralelismo en el reino de Granada», Sharq al-Andalus, 12: 163-177.

${ }^{17}$ A(rchivo) C(atedral) T(oledo). Secretaria Capitular. Sínodo cardenal Quiroga. El redactor de la sugerencia justificaba sus palabras con la siguiente afirmación: «Es verosímil que muchas mujeres de las que consigo llevaron a la sierra irían preñadas, de las quales ay de otras muchas que en tan largo tiempo lo serían, nascieron algunos millares de criaturas, las quales por la poca confiança de fe que en sus padres se debe tener, se cree estarán por baptizar. Por tanto, conviene se haga minuta de los moriscos que están en este arçobispado y se sepa dónde fueron baptizados sus hijos que de tal tiempo ahora pareciere aver nacido, puniendo en ello el remedio que conviene en un negocio de tanta importancia».

${ }^{18}$ La pragmática, en $\mathrm{A}$ (rchivo) M(unicipal) T(oledo). Moriscos. La constitución sinodal de Quiroga estableció la obligación de comunicar al cura de la parroquia ese cambio antes de efectuarse, so pena de dos reales. Efectuada la mudanza, el nuevo feligrés debía comunicarlo al cura o sacristán y quedaba anotado en la matrícula parroquial.

${ }_{19}$ El cadáver era purificado mediante diversos lavados y frotado con hojas de parra y níspero remojadas en agua. Una vez efectuada, pedía perdón quien manipulo al muerto y se procedía a vestirlo con una camisa nueva, quedando envuelto en una sábana de lino a estreno, que era atada arriba o abajo. Los curas debían estar expectantes para que "hallándolos con tales mortajas o almaizares den noticia dello a los vicarios y jueces para que los que lo hicieren sean castigados con todo rigor". Martínez Gil, F. 1993. Actitudes ante la muerte en la España de los Austrias: 601, Madrid: Siglo XXI.

${ }^{20}$ García Pedraza, A. 2002. Actitudes ante la muerte en la Granada del siglo XVI: Ios moriscos que quisieron salvarse: II, 678. Granada: Universidad, apunta el rechazo a la misa. 
Las autoridades diocesanas estaban convencidas de las repetidas desobediencias de esos nuevos cristianos y del incumplimiento de numerosos preceptos sacramentales. Tanto es así que los párrocos recibieron instrucciones de no administrar la eucaristía si no existía una confesión previa, ni tampoco proporcionaban la extremaunción a los moriscos moribundos si antes no otorgaban testamento con un escribano público, en este caso cristiano viejo; incluso indagaban hasta qué punto eran conocedores de las principales oraciones antes de facilitar algún sacramento. Otro símbolo vetado tuvo relación con sus prendas y vestidos, incluso se establecían alertas para comprobar que sus cadáveres eran enterrados en el cementerio habilitado para ellos, impidiendo que los lavasen y fuesen amortajados siguiendo los ritos de su tradición. ${ }^{21}$ Las parteras moriscas, en la misma línea coercitiva, no debían asistir a sus congéneres en el momento de parir, por intuir que dificultaban el bautizo de las criaturas y facilitaban la circuncisión clandestina a los niños. Hay que destacar, en lo relativo a ese proceso de aculturación, que no hubo ninguna disposición para coartar la llamada "solidaridad agnática". ${ }^{22}$ Sí eran decretadas sanciones coercitivas junto con las providencias legislativas, más en concreto, multas pecuniarias para castigar a los renuentes.

Para obtener el mejor conocimiento posible sobre la actitud y comportamiento de los moriscos se implantó un sistema de alerta, cuya efectividad quedaba sustentada en la colaboración de los cristianos viejos con quienes compartían domicilio, ya que los denunciarían en cuanto "hazen alguna ceremonia mahomética". ${ }^{23}$ Por otro lado, las normas emanadas del sínodo buscaron apuntalar el hábito de los nuevos preceptos religiosos en los menores $\mathrm{y}$, para conseguir ese objetivo, los padres debían llevar a sus hijos a la iglesia en la tarde de los domingos con el propósito de instruirles en la doctrina cristiana. Tal adquisición de conocimientos religiosos iba a quedar complementada con el aprendizaje y uso de la lectura y escritura en castellano, una actuación claramente dirigida a hacerles olvidar su lengua y conseguir mayor efectividad en el adoctrinamiento. ${ }^{24}$

Las propuestas allegadas por el clero secular, solicitadas por las autoridades diocesanas, fueron tratadas en el sínodo convocado por el arzobispo Quiroga, recogiéndose una inmensa mayoría de ellas en las actas finales, aunque otras fueron desestimadas. Entre estas últimas hay una que incumbía al ceremonial que acompañaba a la confesión, cuya expresión quedó bosquejada siguiendo estos términos: "Iten, mandamos que quando algún morisco se quisiere y debiere

${ }^{21}$ Gómez Sánchez, D. 1998. La muerte edificada: el impulso centrífugo de los cementerios de la ciudad de Cuenca (siglo $X I X-X X)$ : 49. Cuenca: Universidad, sobre la práctica funeraria de colocar junto al cadáver unos documentos, en alfabeto árabe y tinta roja, llamadas cartas de muerte.

${ }_{22}$ Los esponsales entre cristianos y "cristianos nuevos" se beneficiaron de un relativo consentimiento, en opinión de Pareja Pareja, F. A. 1997, "Los matrimonios mixtos: una estrategia usada por el poder en el proceso de aculturación cristiana”, Qurtuba, Estudios Andalusíes, 2:164173.

${ }^{23}$ García-Arenal Rodríguez, M. 1975. Los moriscos, Madrid: Editora Nacional: 230, trata los aspectos relacionados con la comida y disposición de la casa.

${ }^{24}$ Constituciones Sinodales hechas por el llustrísimo y Reverendísimo señor D. Gaspar de Quiroga. Toledo. 1580. 64-66. Madrid: Imprenta Francisco Sánchez. Comentarios a la pragmática de 1566, en Moreno Díaz, F. J. 2009. Los moriscos de la Mancha: sociedad, economía y modos de vida de una minoría. 281. Madrid: CSIC. La prohibición de hablar en la lengua vernácula, en Vicent, B. 2006, «Reflexión documentada sobre el uso del árabe y de las lenguas románicas en la España de los moriscos (siglos XVI-XVII), en El río morisco, Valencia, 2006: 105-117. 
confesar y no supiere nuestra lengua, para poderlo hacer sin interprete queremos que el morisco tome la mano al confesor secretamente y el ynterprete que hubiese sujeta a tal morisco que quando el confesor y él en su nombre le preguntare si ha hecho el tal pecado, apriete la mano al confesor si lo uviere echo porque quando esta orden no podrá el interprete saber el tal pecado sino solo el confesor" ${ }^{25}$ No es fácil saber la causa para excluir ese texto del soporte legislativo dirigido a fortalecer el valor catequístico y devocional. De entre las conjeturas probables, cabe pensar que los legisladores querían ocultar las dificultades que existían para erradicar el uso de la lengua árabe, una persistencia evidente que quedó manifiesta en la difusión de los escritos aljamiados. Y eso que las pragmáticas los reprobaban y serán perseguidos con denuedo por el Santo Oficio. ${ }^{26}$

La resistencia a la asimilación tuvo visos de ser un ejercicio de obstinación, hecho que facilitó el mantenimiento de los valores de la identidad morisca hasta la expulsión de 1609. Bastantes de esos cristianos nuevos, no obstante, aceptaron el reciente credo y cumplieron sus preceptos con convicción, y aunque hay pruebas que el proceso de aculturación transitó de manera retardada, otras muestran un cambio menos prolongado en el tiempo. Dos indicativos de ámbito no religioso apuntan en ese sentido. El primer indicio positivo a favor del proceso de aculturación tiene que ver con la mudanza que efectuaron numerosos granadinos entre el momento de la llegada y los años finales del siglo XVI. Ese traslado supondrá el abandono de los barrios marginales y su asentamiento en otros menos suburbiales, una señal perceptible al observar como las colaciones parroquiales donde vivían los clientes moriscos del escribano Blas Hurtado ya eran diferentes a las que ocuparon al llegar a la ciudad. La segunda evidencia, comparando diferentes documentos y sus muchos silencios, tiene que ver con la evolución que se produjo en las actividades laborales de bastantes de esos granadinos en el transcurrir de apenas unos años. La mayor parte procedía de áreas rurales y su trabajo se relacionaba con el sector primario, actividad que se mantendrá invariable al instalarlos en Toledo. Poco tiempo después ya se advierte una inversión de oficios, con presencia en sectores como la artesanía y la actividad mercantil, los dos puntales vertebradores de la economía toledana en las últimas dos décadas del siglo XVI y los primeros años de la siguiente centuria. ${ }^{27}$

\section{EXPEDICIONES LLEGADAS A TOLEDO EN 1570}

La salida del reino de Granada tuvo un efecto catastrófico para muchos de los moriscos reubicados en tierras meseteñas. Sobre ese éxodo hay opiniones antagónicas, si bien una inmensa mayoría de historiadores insiste en que fueron abandonados a una suerte cuajada de incertidumbre, con escasos medios para subsistir y obligados a realizar un trayecto de cientos de kilómetros sin los precisos descansos, cuyo resultado final quedó patentizado en miles de muertos. El proyecto

${ }^{25}$ ACT. Secretaría Capitular. Propuestas al Sínodo por el cardenal Quiroga recogidas por el secretario Francisco Pantoja, fechadas el 8 de abril de 1579, f. 4v, con tachaduras. La recomendación sinodal prohibía a los curas facilitar la eucaristía sin la autorización del vicario.

${ }^{26}$ Dedieu. J. P. y García Arenal. M. 1990. "Les tribunaux de Nouvelle Castille», en L. Caidallac (dir.), Les Morisques et I'Inquisition: 276-295. Paris: Publisud. Ansón Calvo, M. C. 1998. «La actividad inquisitorial aragonesa en el reinado de Felipe II y su repercusión en los súbditos moriscos», Martínez Millán, J., Felipe II (1527-1598), Europa y la Monarquía Católica: III: 30. Madrid: Parteluz.

\footnotetext{
${ }^{27}$ Rodríguez de Gracia, H. 1981.
} 
de disgregación comenzó con la concentración en Granada de varios miles, los cuales iban a ser agrupados por localidades de residencia y zonas geográficas precisas; de tal forma que los de la Alpujarra oriental fueron separados de los provenientes de la parte occidental, e igual se hizo con los llegados de la serranía malagueña y los de la vega del Genil. ${ }^{28}$

La conformación de las partidas quedó al cuidado de unos comisionados, quienes empleaban un criterio impreciso al efectuar su trabajo, hasta el punto de conformar las cuadrillas sin tener en cuenta que no debían juntarse los que tomaron las armas con los denominados "moriscos de paz". O lo que es igual, los no involucrados directamente en la lucha, cuya causa de expatriación resultó ser un efecto colateral del conflicto al quedar aprisionados entre los sublevados y fuerzas reales. En cualquier caso, las instrucciones del monarca Felipe II iban dirigidas dejar los menos posibles en la tierra de sus ancestros. ${ }^{29}$

El día uno de noviembre salían los primeros expulsados de Granada. Hasta final de mes no llegaban a tierras toledanas y cubrían la primera fase del periplo, ya que un buen número de ellos sería trasladado a otros puntos geográficos. ${ }^{30}$ Las referencias documentales conservadas apuntan a un total de 2.508 individuos como integrantes de aquella caravana, aunque los asignados en principio por partida eran muchos más, ${ }^{31}$ tal y como reflejan las reales órdenes de 2 y 19 de noviembre de 1570 y ratifican las instrucciones dadas a los cuadrilleros encargados de su conducción. Si la estimación numérica resultó equívoca, en tal error tuvo mucha culpa la cuantificación inicial del contingente, fijada en 6.000 personas, ya que debía fragmentarse en cuatro grupos de 1.500 cada uno, como sugería la orden regia.

A finales de noviembre arribó otra partida, cuyo número no puede precisarse con los datos existentes en la documentación conservada. De manera temporal iban a permanecer en las localidades de Consuegra, Quintanar de la Orden y Tembleque, cosa que no sucedió. Enseguida serán puestos en ruta hasta quedar todos agrupados en Toledo, donde estaba proyectado volver a confeccionar una lista general con otras cuadrillas que iban a llegar posteriormente. ${ }^{32}$ Esa

${ }^{28}$ Vincent, B. 1970. «L'expulsion des morisques du Royaume de Grenade et leur répartition en Castille (1570-1571)», Mélanges de la Casa de Velázquez 6: 222, apunta las rutas utilizadas para el desplazamiento desde Granada. Una llegó a Ciudad Real, otra procedía de Antequera y concluyó en Plasencia, la tercera pasó por Albacete, desembocó transitoriamente en Toledo, para continuar hasta Ávila, Salamanca y Zamora..

${ }^{29}$ Las escuadras compuestas por 1.500 personas son citadas por Caro Baroja, J. 1976. Los moriscos del reino de Granada. Ensayo de historia social: 62,154 y 204. Madrid: Istmo. Domínguez Ortiz, A. y Vincent, B. 1978. Historia de los moriscos. Vida y tragedia de una minoría: 50. Madrid: Revista de Occidente.

${ }^{30}$ El decreto de expulsión para Castilla tiene fecha del 1 de noviembre de 1570, aunque desde fines del año anterior ya llegaban algunos expulsados a tierras castellanas, Santamaría Conde, A. 1981: 39-48. La arribada a zonas manchegas, Moreno Díaz del Campo, F. J. 2004. «El discurrir cotidiano o la convivencia frustrada: los moriscos granadinos en el campo de Montiel», Cuadernos de Estudios Manchegos, 28: 93-142. La vigilancia es tratada por Dedieu, J. P. 1983. «Les Morisques de Daimiel et l'Inquisition (1502-1526)», Les Morisques et leur temps. 493-522. París: CNRC. "Morisques et vieux chrétiens à Daimiel au XVlème siècle», Temimi, A. 1984. Religion, Identité et Sources Documentaires sur les Morisques Andalous: 199-214 Tunis: P.I.S.D.

${ }^{31}$ Vincent, B. 1971. «Combien de Morisques ont été expulsés du royaume de Grenade?», Mélanges de la Casa de Velázquez, VII: 187-222. También Vincent, B. 1970: 225.

32 Lapeyre, 1986:136, apuntan un total de 3.032 moriscos recogidos en Toledo y en los pueblos de su jurisdicción, aparte de los recibidos en los partidos de Talavera, Escalona o Alcalá. 
imprecisión de la fuente dificulta concretar el total de los establecidos en la ciudad a finales del año 1570. Existe, pese a los inconvenientes, una valoración sólida al respecto, y es el recuento efectuado por el alcalde de casa y corte Hernán Velázquez, efectuado en abril de 1571, cuya cuantía numérica fija en 1.879 moriscos los avecindados en la ciudad, con preponderancia de mujeres sobre hombres. A esa cifra hay que añadir otros 750 esclavos "de buena guerra"; ${ }^{33}$ tal es así que, de ser válidos los datos de residentes, su total superó en muy pocos los 2.600 granadinos. ${ }^{34}$

Otros grupos ya habían recalado a partir del 20 de noviembre, y lo hicieron de forma intermitente. Venían de Albacete y Chinchilla, ${ }^{35}$ lugares únicamente de confluencia, casi a mitad del trayecto, donde fueron agrupados ante la pluralidad de los puntos de origen. La primera partida en arribar estaba compuesta, supuestamente, por 1.500 personas, solo la cuarta parte de los indicados en la orden. Quedaban concentrados en un campamento establecido en Burguillos, a unos once kilómetros de la ciudad, donde permanecieron por breve espacio de tiempo antes de ser reexpedidos a otros puntos geográficos meseteños. Previamente a la salida para su nuevo destino, el corregidor toledano consideró imprescindible confeccionar otro registro y de esa manera organizar las cuadrillas de forma más o menos ponderada. El escribano público dio fe de cuántas personas integraban cada una de las cuadrillas, pero solo quedan referencias de la inicialmente constituida por 645 hombres, mujeres y niños, según el recuento efectuado antes de salir de Granada, puesto que llegaban 624 a Toledo y los 21 restantes quedaron internados en los hospitales o enterrados en el trayecto; sepultados, cabe advertir, sin ningún respeto al rito islámico.

Un rasgo significativo de esos folios es que el escribano efectuaba el asiento por "casas". El epíteto, utilizado como sinónimo de familia, facilita saber cuántas personas componían cada hogar; o dicho de otra forma, cuántos integraban el grupo doméstico corresidente. La relación nominal comienza con el nombre del cabeza de familia, hombre o mujer, y sigue con el patronímico de los otros miembros de la unidad, tanto si el hogar estaba completo como si correspondía a una familia incompleta. Otras notas identificativas que incluye son la profesión que ejercían, su edad y el lugar de naturaleza. Aquel grupo provenían de dos localidades del marquesado de Cenete llamadas Jerez y Lanteira. ${ }^{36}$.

\begin{tabular}{|l|l|l|l|l|l|l|l|l|}
\hline Uno & Dos & Tres & Cuatro & Cinco & Seis & Siete & Ocho & Personas \\
\hline 34 & 72 & 50 & 31 & 20 & 6 & 2 & 2 & Hogares \\
\hline
\end{tabular}

\footnotetext{
Moreno Díaz, 2009: 88 y ss., incluye las cifras de los agrupados en las poblaciones manchegas.

${ }_{33}$ Martz, L. 1983. Poverty and welfare Habsburg Spain: 96. Cambridge: UP, según los datos obtenidos de AGS. Cámara de Castilla, legajo 2162.

${ }^{34}$ Kagan, R. L. 1994. "Contando vecinos: el censo toledano de 1569», Studia Historica. Historia Moderna, XII: 116-135, calcula la población en 12.248 vecinos, o lo que es igual, 51.181 habitantes, mas 921 clérigos y 1.668 religiosos, lo que hacía un total de 53.770 personas.

${ }^{35}$ Santamaría Conde, A. 1984. "Albacete y la deportación general de los moriscos granadinos», II: 36 Actas I Congreso de Historia de Albacete, Albacete: I.E.A.

${ }^{36} \mathrm{La}$ distribución porcentual, sin decimales, fue de un $47 \%$ para Jerez y de un $53 \%$ para Lanteira. AMT. Moriscos, legajo 1686, registro de los 645 moriscos.
} 
La fuente transmite nueva información en relación con el número de individuos que formaba cada unidad familiar. Predominaron los hogares formados por dos y tres personas, tal y como figura en el cuadro. Eran familias nucleares integradas por un matrimonio sin hijos, con un único vástago, y una viuda o viudo con dos hijos. La generalidad no resulta tan absoluta como en principio parece, puesto que también hubo hogares formados por seis, siete u ocho individuos; es decir, la llamada familia múltiple. La relación mencionada subraya una prodigalidad de casas integradas por la madre, o el padre, y dos hijos, aunque hay muestras de hogares compuestos por nietos y abuelos; o lo que es lo mismo, familias incompletas. ${ }^{37} \mathrm{El}$ predominio de hombres sobre mujeres es connotativo en los núcleos de una sola persona, convirtiéndose en nota significativa sobre todo porque quienes pelearon en el levantamiento eran varones, y fueron los que más murieron en combate, mientras las mujeres y niños intervinieron de forma menos directa. Un caso tan específico no es fácil de explicar. Pudo deberse tal alteración a quedar las mujeres adscritas a un grupo diferente o a que fuesen separadas en el recuento inicial, algo que chocaba con el mensaje de la pragmática que imposibilitaba dividir a las familias. En fin, aquella singularidad es cambiante y disímil si se confronta con la estructura de otras cuadrillas.

El cuadro refleja otro rasgo axiomático, y tiene que ver con la exigüidad de grupos domésticos constituidos por más de seis personas. El número de hogares complejos es limitado y deja desmitificada la idea de la existencia de familias extensas y múltiples entre los que llegaban. Distinto es lo que ocurrió una vez asentados. Queda constancia, empero, de progenies abundantes en los registros del escribano Sotelo, como el hogar de Francisco Albuzate, originario de Lanteira, con mujer y seis hijos, de edades comprendidas entre doce y seis años. Un prototipo similar será el representado por el hogar de Pedro Lozano, también de Jerez, compuesto por su mujer, cuatro hijos y una "morena negra", presuntamente su esclava. ${ }^{38}$ Ese tamaño del hogar es signo que marca la diferenciación económica y social entre éste y los otros desterrados. ${ }^{39}$

La fuente ofrece una información complementaria al constatar la presencia de bastantes parientes de primer grado, madre, padre o hermanas, acogidos en el hogar del cabeza de familia. Muy al contrario, resulta poco habitual hallar a familiares de la mujer acogidos en esa casa. En ese mismo orden de evidenciar peculiaridades, la relación recoge a más de un centenar de personas que vinieron solas, una estructura familiar de solitarios que permite resaltar la irracional fragmentación efectuada en su punto de origen. De haberse hecho a propósito, quedaría en evidencia una clara vulneración de las instrucciones reales, al destinar

${ }^{37}$ La diferencia de edad en los 143 matrimonios completos que aparecen en la relación es llamativa; tal es así que 62 hogares presentan menos de cinco años de discordancia y esa disparidad es de entre seis y diez años en 79 parejas. Con más de una decena de años hay únicamente dos parejas.

${ }^{38}$ Los moriscos con esclavos negros, en Cortés López, J. L. 1989. La esclavitud negra en las España peninsular: 72 Salamanca: Universidad.

${ }^{39}$ La sustitución de los moriscos por cristianos viejos y la necesidad del cultivo de las tierras obligaron al establecimiento de un modelo de repoblación cuyo principal órgano ejecutivo fue el Consejo de Población. Analizado por Quesada Morillas, Y. 2008. "Los moriscos del reino de Granada: su expulsión y el Consejo de Población», Revista Electrónica de la Facultad de Derecho de la Universidad de Granada. 
a mujeres y maridos a diferentes lugares o reubicarlos en distintas partidas. Cabe pensar, elucidando en busca de respuesta, que pudieron darse otras circunstancias para efectuar una fragmentación semejante, bien que los maridos quedasen huidos en la sierra, hubieran muerto en el transcurso de la revuelta, bien que pereciesen durante el trayecto o escapasen en la marcha al control de los cuadrilleros. No menos dificultoso es precisar cuántas mujeres de las que llegaban en este grupo eran viudas, ya que su estado no está aclarado con un vocablo preciso.

Otro indicador que figura es la edad, un dato que más o menos consta en un $85 \%$ de los 624 relacionados, y permite construir una pirámide de edades, con alguna imprecisión ante las erratas que contiene la fuente. Aun así, el modelo presenta ciertos patrones de interés, más en concreto, cuatro intervalos que ayudan a obtener resultados. Veamos cada uno en detalle. En el primero están agrupados quienes contaban de 46 a 50 años y concentraba 60 hombres y un número semejante de mujeres. El segundo grupo estuvo integrado por el segmento de los que tenían entre 26 y 30 años y en él fueron contabilizados 44 mujeres y apenas un hombre, lo cual llama mucho la atención. En el tercer intervalo aparecen los de entre 36-40 años, con 41 hombres y 26 mujeres. El último lugar lo ocuparon los comprendidos en el intervalo 56-60 años, un sector representado por 45 hombres y 11 mujeres, como puede verse en el cuadro incluido a continuación. No deja de ser reveladora la insignificancia de mayores de 70 años, cuya nimiedad no es tal en el tramo 66-70 años, donde figuran 6 varones. Evidencia resaltable es la abundancia de niños frente a niñas, más en concreto en los grupos comprendidos entre los 0 y 5 años y 6 y 10 años. Las cifras totales, a modo de conclusión, confirman el predominio de hombres frente a mujeres, al sumar los varones 368 y las mujeres 254, una supremacía que, aun siendo generalizada en todos los tramos, es mayor entre 0 y 20 años. En ese espacio cronológico, los del sexo masculino sumaban 140 , frente a 64 mujeres, una desigualdad que vuelve a ser evidente en la franja comprendida entre los 56-60 años. Las cifras, en definitiva, dejan ver como los menores de 40 años sumaban 432, mientras los que superaban ese límite apenas eran 192. Esa singularidad posibilita ratificar que con esta partida llegaron gentes relativamente jóvenes, quizá porque los viejos quedaban, por múltiples circunstancias, en el camino.

Grafico I. Edades de los moriscos

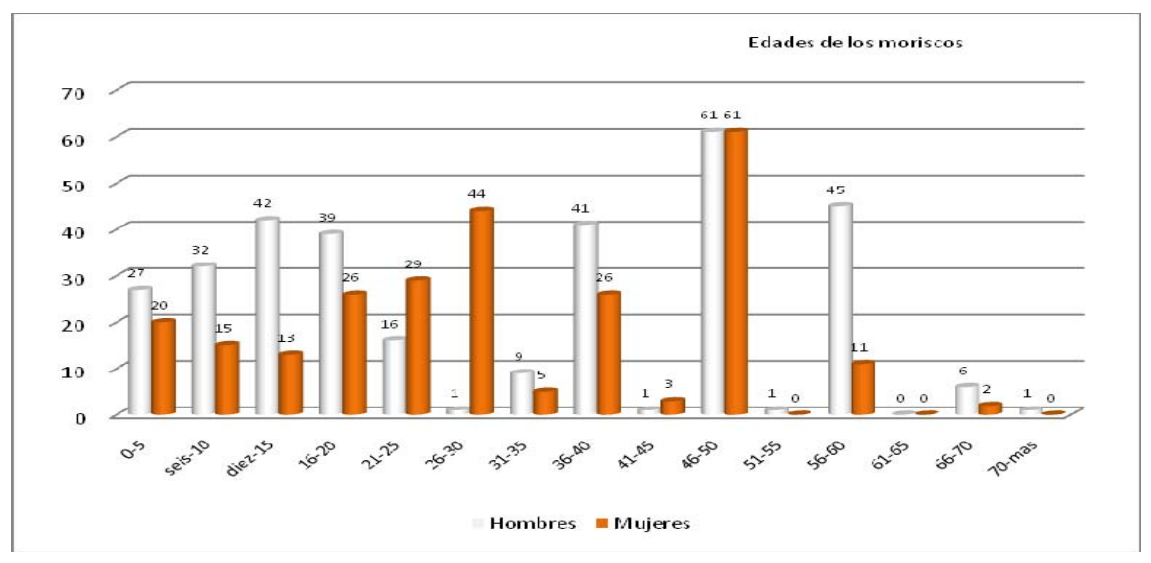

La siguiente cuestión a tratar tiene que ver con la ocupación laboral, a primera vista caracterizada por la uniformidad en el empleo, al ser distribuidos, nada más 
llegar a la ciudad, como sirvientes y criados de ciudadanos con un nivel social medio-alto. Otra fracción quedó bajo el amparo de varias docenas de personas caritativas, un término eufemístico empleado aquí al prestarles cobijo sin contraprestaciones hasta que hallasen acomodo. ¿Qué criterio utilizó el corregimiento a la hora de colocar a los moriscos recién llegados? La respuesta es que aquel proceso de asiento siguió unas pautas precisas. El primer paso consistió en dejar registrado el nombre del receptor y su profesión; o lo que es igual, quién tuvo bajo su custodia a un granadino, por interés o por compasión. A continuación, debajo del dato anterior, está detallado el patronímico del morisco adjudicado, el de los componentes de la unidad familiar, su edad, vinculación familiar (hijo de...), para concluir ese asiento con la firma del receptor. Un análisis pormenorizado de cada recepción manifiesta que las mujeres jóvenes fueron las primeras asignadas, luego llegó el turno a los adolescentes y, por último, serán distribuidos los niños, con toda probabilidad huérfanos al no encontrarse sus padres en ese registro.

Las posibilidades laborales para esas gentes presentaron un espectro sectorial bastante limitado ante su procedencia, con predominio de los que venían de un medio rural frente a los de un medio urbano. Por tal circunstancia, una buena parte de ellos será entregada para realizar tareas domésticas. Otros, muy inferiores en número, ejercieron de aprendices en algunos de los numerosos oficios urbanos, mientras un número indeterminado llevó a cabo actividades de escasa cualificación en el sector terciario. En relación con su situación jurídica, la mayor parte de los menores que figuran en la lista onomástica estaban esclavizados, lo cual hace pensar que no fue respetado su derecho a la libertad y condenados a priori a una servidumbre generalizada, aunque la normativa jurídica planteaba excepciones. En tal sentido, la libertad resultó reversible en casos muy contados. Únicamente si el subyugado podía probar que no era tal. Esa alteración requirió de un proceso lento; aun así no faltaron las demandas para conseguir una sentencia favorable. Los adquirentes, una vez conseguida la sentencia en su contra, tuvieron que conceder la manumisión a sus pupilos, una libertad limitada, ya que debían obtener un pasaporte para ir de un sitio a otro fuera de la ciudad. Alguna ventaja obtuvieron, como la de efectuar con su empleador un contrato, en cuyo instrumento quedaban resaltadas dos condiciones básicas: el coste del salario y el tiempo de duración del servicio. Las demandas presentadas ante el tribunal del alcalde mayor posibilitaron revertir la condición de servidumbre para algunos, sobre todo aquellos que en las pragmáticas estaban exceptuados por su edad. La persistente reticencia de los amos en consentir la libertad obligó a establecer medidas coercitivas y multas para los renuentes. ${ }^{40}$

Sobre la esclavitud de los moriscos toledanos existe un estudio todavía inédito. Su autoría corresponde Esperanza Pedraza, ex archivera municipal, y contiene observaciones muy precisas sobre los cautivos que quedaron inscritos en el recuento efectuado el año 1573, casi tres años después de la primera arribada. Los niños contabilizados fueron 377 , de uno y otro sexo. La cifra, nada despreciable, permite hacer hincapié en ciertas particularidades, ${ }^{41}$ sobre todo en la

\footnotetext{
${ }^{40}$ AMT, Morisco, 1686, escritura de obligación otorgada por Diego López de Mora, vecino de Toledo, comprometiéndose a tener a su servicio a Isabel Mejía, por un periodo de cinco años.

41 Conclusiones muy provechosas en el estudio de Pedraza, 1985. El tema de la esclavitud es tratado con amplitud por Peñafiel Ramón, A. 1991. Amos y esclavos en la Murcia del Setecientos: 147-149. Murcia: R.A. Alfonso X el Sabio.
} 
distribución parroquial donde habitaban los patronos. El arco de asignación presentó la siguiente composición: 56 granadinos fueron dejados en la circunscripción de Santo Tomé, frente a solo 5 que fueron acoplados en la colación de San Bartolomé y 39 en la capilla de San Pedro. Los vecinos de los santos Justo y Pastor acogían a 23, otros 28 estaban en la colación de San Andrés, 17 en la de San Cristóbal, el mismo número recibían los de la parroquia de San Román, 19 quedaron registrados en la San Salvador, otros 41 eran entregados a vecinos del distrito de San Nicolás, 29 en San Vicente, 14 estaban al cuidado de residentes de la colación de la Magdalena, 34 en Santa Leocadia, 14 en el minúsculo enclave de San Ginés, 11 vivían en San Juan Bautista, aparte de otros siete en San Miguel, dos en San Martin, siete en San Lorenzo y cuatro fueron entregados a patronos que vivían en el distrito de san Cipriano.

Las cifras anteriores permiten efectuar dos razonamientos. El primero es de tipo económico y evidencia que sus receptores los dedicaron, por lo general, a trabajar en actividades domésticas, sin una clara especificación. Ellas quedaron al servicio de las mujeres de la casa y ellos fueron destinados como mozos de todo tipo o aprendices de profesiones artesanales. Su atractivo no pudo ser otro que su bajo coste como fuerza productiva, al tratarse de muchachas y muchachos dúctiles, de fácil instrucción en un oficio y con ningún salario. La categoría social del empleador, en segundo lugar, presenta un arco nada despreciable, si bien predominan los receptores de cierta envergadura económica y social, aunque otros eran simples artesanos u oficiales de empleos diversos. Este detalle conduce a otra correlación: el mayor número de moriscos se asignó a toledanos que vivían en las colaciones donde el índice de pobreza era bajo, mientras en los distritos poblados por gente de limitados ingresos apenas si se dejaron. En ese sentido solo quedó uno a cargo de un patrón en la circunscripción de San Isidoro.

El estudio de Pedraza ofrece otras apreciaciones enjundiosas. En ese componente es menor el predominio de hombres, al sumar estos 62 , frente al de mujeres, cuyo número ascendió a 126. La misma superioridad vuelve a ratificarse con los niños, cuya cifra era de 94, frente a 106 niñas. De ese conjunto, un total de 111 mostraban señales de cautivos, sin distinguir sexo, mientras 107 no estaban herrados. Las cifras son bastante equilibradas, ${ }^{42}$ aunque llevan a interrogantes de dificultosa aclaración como, por ejemplo, por qué unos y otros fueron considerados esclavos. Recordemos que quienes carecían de la marca no debían tener esa condición y, por otro lado, debían ser libres los que no traspasaban cierta edad. La impresión es que quedó bastante incumplido ese requisito con aquiescencia de las autoridades, circunstancia que produjo un hueco jurídico que sería aprovechado para conseguir la libertad de algunos de esos niños, con grave quebranto económico para sus amos al perder las cantidades pagadas a los vendedores, buena parte de ellos soldados. Lo cierto y verdad es que la condición de cautivo resultó dificultosa de revertir, a no ser que quedase demostrado que las instrucciones sobre los botines habían sido ignoradas; ${ }^{43}$ algo no imposible, pero

42 AMT. Libro del registro de los moriscos que su magestad hace por su provisión y pragmática. Año 1573, sig. 174.

43 AMT. Moriscos, legajo 1687-88, julio de 1573, septiembre a octubre. Proceso seguido contra Vasco de Guzmán, vecino de Toledo, por haber cogido cautiva, antes de tener diez años, a una morisca llamada Lucía, hija de Diego Medrano y Sabina. Del comercio de esclavos hay referencias en los protocolos, entre ellos la compra de dos esclavos herrados, procedentes de 
con numerosos escollos burocráticos. Algunos lograron tener éxito en su empeño, como sucedió a un tal Ginés, con apenas seis años de edad, ${ }^{44}$ cuando sus parientes reivindicaban ante el corregidor el cumplimiento de la pragmática real; puesto que no podían estar esclavizadas personas menores de diez años y medio, si eran de sexo masculino, y de un año menos en el caso de ser mujeres. Su dueño, el rico mercader Juan Sánchez Cota, justificó su inocencia y argumentó que no figuraba su edad en la escritura de compra protocolizada con el vendedor, un soldado llamado Álvaro López. El alcalde mayor reconoció que no tenía diez años y dio por nula la compra. No obstante, permitió que permaneciera al servicio de su patrono a cambio de recibir un estipendio, cuyo valor dejó al arbitrio del mercader. Aquel no es un caso único, y otros certificados evidencian un incumplimiento sistemático de las pragmáticas por parte de los captores, un motivo esencial para obtener la libertad.

A la hora de conocer la distribución por sexos de los esclavos repartidos durante el año 1570, es muy provechoso el expediente de los 624 moriscos. Allí hay bastantes referencias sobre la edad de los muchachos y muchachas; con alguna laguna, bien es verdad. Los asientos confirman que fueron bastantes los toledanos beneficiados por esa operativa. Su intención no era otra que disponer de jóvenes sirvientes sin estipendio e incluso algún receptor los puso a trabajar y cobraron sus emolumentos. Buena parte cumplió el convenio en toda su extensión y declaraban el valor del jornal acordado, como especifica la siguiente referencia: "Toledo, treinta días del mes de noviembre de mil quinientos setenta, Alonso de Quiros, alcalde ordinario, rescibio a Rafael de Martos, vecino de Xerez, de quarenta años, y a Maria, su mujer, de treinta años, por dos meses, por un ducado cada mes y de comer". ${ }^{45}$

En el registro aparecen algunos vacíos. No son capitales y llevan a intuir ciertas añagazas, como la comentada ocultación del precio del salario y una sistemática omisión de la edad. El silencio tenía sentido, porque con esa actitud se esclavizaba a quienes estaban excluidos de los límites fijados por las órdenes reales. Las lagunas sobre la procedencia deben interpretarse como una acción intencionada con el propósito de borrar la huella de su origen, aunque, en menor medida, pudo ser una omisión del escribano. ¿Acción premeditada? ¿Involuntaria y fruto de una negligencia? Más bien lo primero que lo segundo. En dicho registro, como prueba ilustrativa, aparece un tal Gómez Carrillo asumiendo la custodia de nueve personas con apellido Valenciano, sin que conste el estipendio convenido ni la edad de ninguno. La misma disposición vuelve a repetirse cuando el calcetero Juan Sánchez recibió a siete adultos, a los cuales puso a trabajar en su taller. En fin, son notas ilustrativas a unas omisiones iterativas, porque el modelo de la cesión seguiría unas pautas semejantes a esta: "este día Francisco de León, mercader,

Antequera, por Juan Francisco Ortiz, vecino de Toledo, AHPT. Protocolo 1881, f. 316, año 1583, escribano Jerónimo Castellano.

${ }_{44}$ Pedraza, E. 1985: 382. Los familiares aportaban dinero al fisco real por la redención, como deja claro el depositario general de alcabalas, Juan Sánchez de Cisneros, al declarar que tenía en su poder 127.278 mrs., abonados por la emancipación de moriscos. AHPT. Protocolo 11653, noviembre, 1574, f. 404, escribano Diego Sotelo.

${ }^{45}$ AMT. Moriscos, leg. 1686, exp. 2, registro de los 645 moriscos. 
vecino de Toledo, vive a la casa de don Pedro de Mendoza, rescibio a Maria, hija de Juan Díaz, vecino de Xerez, de edad de quatro años". 46

Los no acomodados en los primeros días de estancia en la ciudad, un grupo constituido por 203 personas, quedaron bajo la custodia de los jurados Alonso de Cisneros y Francisco de Torres. Ante tal número de parados, valga el eufemismo, el protocolo de asignación será repetido en días posteriores, y los jurados imprimieron una notable urgencia en su trabajo por que corría a cargo del ayuntamiento su sustento y querían evitar mayor gasto. Otros quedaron recluidos en corrales hasta el momento de hallar para quien trabajar, situados en las parroquias de los santos Isidoro, la mayoría, y Cipriano. Unos pocos quedaron asilados en casas de particulares, que cumplían con las obras de misericordia. Las presiones de las autoridades eclesiásticas sobre esos feligreses tuvieron su efecto, aunque hay que leer entre líneas para captar que quizá se pretendía no tanto auspiciar esa ayuda humanitaria como hacer que la vigilancia resultara efectiva. Hubo un grupo, en número poco significativo, necesitado de remedios médicos que quedó internado en el hospital de Tavera.

El cuadro está todavía incompleto y requiere de otras pinceladas para su conclusión. El hacinamiento, por ejemplo, que soportaron los alojados en la colación de San Isidoro, apiñados en corrales y viviendas paupérrimas, compuestas por cercados construidos de tapial, material habitualmente empleado en edificaciones destinadas a recoger a gallinas, cabras y animales de labranza. Al ser establos insuficientes para alojar a tantas personas, debieron dormir a la intemperie y sin resguardo, algo determinante para que empeorase su deficiente salud. ${ }^{47}$

Los empleadores pretendieron obtener con ellos un beneficio, pagando su trabajo a muy bajo coste ${ }^{48}$ al ser de escasa cualificación los oficios que ejercieron. Aun así los toledanos, de todas las capas sociales, aprovecharon esa circunstancia para lucrarse con un hacendoso granadino, un chico o una chica, incluso una pareja de más de treinta años; jornal ajustado, con reiterada frecuencia, a un vestido, calzado, escasa comida y en última instancia al pago de unas contadas monedas, abonadas bastantes años después de haber prestado el servicio. ${ }^{49}$ No es de extrañar, pues, que tal situación tuviera cierta incidencia en el despegue

${ }^{46}$ El patrón seguido en estas reseñas es el siguiente: "este día Miguel Sánchez, lavorante de lana, bibe a san Cebrian, rescibio a Leonor, biuda, mujer de Hernando de la Puerta, vecino de Xerez". Hay otros ejemplos, como el de Andrés Hernández, vecino de Toledo y heredero en Polán, que recibió a quince personas, sin que apareciese entre ellas ningún niño. El escribano Alonso Sotelo, por otro lado, acogió a un tal Francisco Domingo, de 18 años. Las lagunas son más abundantes en lo relativo a la localización del domicilio del receptor o su profesión; aun así hay descripciones completas.

47 El hacinamiento, en Rodríguez de Gracia.1982: 525. Para la descripción de la casa, Hurtado de Toledo, L. 1951-63. «Memorial de algunas cosas notables que tiene la Imperial ciudad de Toledo", "de la forma y traça de las casas de este pueblo y de que materiales están fundadas...". en Paz R. y C. Viñas (trans.), Relaciones histórico geográficas de los pueblos de España. III, 35:509510 Madrid: CSIC.

${ }^{48}$ Andújar Castillo, F, 1992-93: «Del esclavo morisco al berberisco: sobre la esclavitud en Almería en el siglo XVIII». Boletín del Instituto de Estudios Almerienses, 11-12:81-101, con sugerencias sobre la problemática.

${ }_{49}$ María Méndez, superiora del convento de Santo Domingo el Real, recogió a Cecilia, una chica huérfana, con 15 años, en calidad de criada. Otros ejemplos ilustrativos son el del mercader Baltasar de Herrera, que tomó a María, de Cogollos, con ocho años; mientras Damián Navarro, un sombrerero domiciliado en la puerta de Doce Cantos, se hizo cargo de un niño, con solo tres años, "que le dio su madre María, mujer de Pedro Mexía, vecino de Lanteira". 
económico del último tercio del siglo XVI. A la casuística descrita se añadieron bastantes abusos y algunos "señores" -valga el tropo especulativo- dispusieron en su casa de alguna mujer joven para realizar tareas domésticas, incluidos ciertos menesteres espurios.

En las áreas rurales, los impúberes moriscos soportaron con mayor rigor las injusticias. Muchas quedaron silenciadas y otras no permanecieron enmudecidas. Diego Fernández, un morisco de Esquivias, junto con otros padres, denunció a varios cristianos viejos, inculpándoles de cometer atropellos contra sus hijos, según evidencia una solicitud de amparo dirigida al alcalde mayor de Toledo en el mes de junio de 1573. Acusaron a las autoridades de la población de llevarse a sus muchachos a trabajar en las casas sin mediar el consentimiento paterno, ni pagar estipendio ni con la intención de enseñarles un oficio. Los padres justificaban que con tal forma de actuar transgredían las órdenes reales y convertían a libres en cautivos. Los progenitores quisieron reconducir el problema y exigieron un salario a los patronos. Como respuesta recibían unas despiadadas amenazas, y no mostraron temor a las denuncias que, en el improbable caso de obtener un pasaporte de tránsito, pudieran interponer ante tribunal del alcalde mayor toledano, al estar coaligados y emparentados con los miembros del concejo de la localidad. ${ }^{50}$

\section{OTRAS PARTIDAS INTEGRADAS EN LA DE LOS 6.000 MORISCOS}

A finales del mes de noviembre de 1570 llegó a Yepes un grupo con 500 moriscos. ${ }^{51}$ Los mandaba el regidor de Úbeda Rodrigo Monsalve y firmó su recepción el alguacil mayor Álvaro Zúñiga. ${ }^{52}$ Sin apenas descanso, ni valorar las penalidades de un camino tan largo, los condujeron hasta la ciudad, no a todos porque ya fallecieron algunos en la ruta. ${ }^{53}$ No alcanzaron aquellas muertes un valor

50 AMT. Legajo 1687-88, expediente núm. 9. En junio de 1571, el corregidor Velázquez exigió a quienes tenían criados moriscos acudir al escribano Sotelo para extender los contratos de servicio. Reflejaría el escribano el tiempo de duración y el valor de su trabajo, una reticencia sancionada con 10.000 maravedíes. AHPT. Protocolo 1647. f. 360, año 1577, escribano Juan Sotelo. Ejemplo de la tenacidad por conseguir su libertad es el de María de Uxíjar, traída como esclava por Sebastián de Ávila y vendida a Pedro de Ávila, vecino de Toledo. Estuvo a su servicio por espacio de siete años, aunque su madre, Isabel de Uxíjar, puso una demanda ante el alcalde mayor. El tal Ávila decidió, antes de la sentencia, conceder la libertad a la muchacha y abonar por su trabajo diez ducados, además de entregar unas ropas. Otros padres pagaban un rescate, como una forma rápida de recuperar a los hijos o mujeres, como hizo Lorenzo Dueñas, natural de Berja, AHPT. Protocolo 1653, f. 130.

${ }^{51}$ Vincent, 2006, El río morisco: 19, no halla doncellas viviendo en el hogar del hermano. En un registro efectuado por el corregidor Gutiérrez Tello, durante el año 1573, hay una nota que apunta a cómo María Ramírez vivía con su hermana Brianda y su marido. Otra mujer, llamada Isabel, estaba en casa de Alonso Vázquez, casado y hermano. AMT. Moriscos, 1686, Registro de los 645 moriscos traídos por Rodrigo de Monsalve.

52 Se hallaban recogidos en los alrededores de un mesón "que dicen de doña Ana", situado a la entrada de la población. En la relación figura el nombre, profesión, edad, y componentes de cada hogar, además de constar que algunas mujeres portaban bienes, los cuales debían quedar a salvo y en su poder, según unas comunicaciones remitidas por el Consejo y Chancillería.

${ }^{53}$ Sobre la mortalidad referida hay una carta escrita en Toledo el 23 de noviembre de 1570, Dadson, T. 2007. Los moriscos de Villarubia de los Ojos (siglos XV-XVIII). Historia de una minoría asimilada, expulsada y reintegrada: 137. Madrid-Frankfurt am Main: Iberoamericana-Vervuert. Martz, L. 1983:96, fija el índice de mortalidad en un 40\% y Pedraza, E. 1985: 30, afirma que el número de bajas durante el viaje fue del $20 \%$. Durante el bienio $1570-71$, los valores de la muerte se situaron en un 33,8\%, según Carrasco, R. 2009. Deportado en nombre de Dios: 79, Barcelona: Destino. En los documentos, las cifras absolutas son menores para la cuadrilla de Cristóbal Balsada, 
numérico desmedido, si bien sirve de indicador para tantear la desgracia el hecho de que los 12 de los ingresados en el hospital de Tavera fenecieran a los pocos días. La cifra es relativamente insignificante, apenas un $2,5 \%$, teniendo en cuenta las múltiples calamidades soportadas en su periplo por las llanuras de Albacete y la Mancha. Tampoco el porcentaje es transcendente si se compara con las estimaciones efectuadas por otros historiadores, ${ }^{54}$ cuando apuntan que las condiciones meteorológicas, propias de un gélido otoño, las largas caminatas diarias y los escasos bastimentos alimenticios dejaron el camino sembrado de cadáveres. $^{55}$ Al llegar a Toledo eran cuerpos famélicos. Tanto es así que los jurados Francisco Sánchez de Sampedro y Alonso García de Santa Cruz, el arcediano, y un clérigo apellidado Serna, tomaron a su cuidado un total de 170 personas y procuraban albergarlos en los hospitalitos de San Pedro, San Miguel, San Antón, Santa Ana, San Andrés, etc. ${ }^{56}$ El rector del hospital de Afuera socorrió a los que presentaban una dolencia irreversible, aparte de mostrar síntomas de inanición y pocas ganas de vivir. De ellos, 39 estaban en un estado tan terminal que fenecieron a los pocos días, sepultándoles en un muladar cercano a la puerta de Bisagra, con notable desprecio a sus creencias al ser un lugar que servía de pudridero de las bestias.

La teórica expedición constituida por "seis mil moriscos", que comenzó a llegar a partir del 22 de noviembre de 1570, estuvo compuesta por varias partidas, como ya se dijo con anterioridad. Una vino al mando del capitán Luis de Córdoba y fue instalada temporalmente en las localidades de Yébenes, Orgaz, Ajofrín y Mazarambroz, en el trayecto Toledo-Ciudad Real. Apenas habían pasado cuatro días de su arribada y los enviaban a Burguillos, donde comenzó la elaboración de un nuevo registro para tener constancia de cuántos sumaban los que iban asignados a diversas localidades de Castilla la Vieja ${ }^{57}$. Aparte de que resultaba adecuado rectificar las cifras iniciales ante las bajas experimentadas desde mitad del trayecto, por el número de escabullidos que hubo, unos huidos y otros entregados en el recorrido como esclavos, más los enfermos y agonizantes encomendados a las autoridades de los pueblos del camino.

La distribución tuvo lugar el 25 de noviembre y quedaban constituidos en dos grupos parejos. Uno saldría al mando de Alonso de Sandoval y el otro será guiado por Antonio de la Hoz. ${ }^{58}$ Los capitaneados por Sandoval fueron organizados para una salida inmediata ${ }^{59}$, un operativo que comenzó muy temprano y quedó

al morir solo 10 personas de un total de 469; y más elevadas en la de Valderey, ya que fallecían 53 de un total de 831 moriscos.

${ }^{54}$ Lapeyre, H. 1986: 125, citado por Vincent, B. 1970:241.

${ }^{55}$ Aranda Doncel, J. 1984:65, refiere el calamitoso estado de los expulsados granadinos.

56 ACT. Libro de actas capitulares 1568-1574, martes 22 de diciembre de 1570, el cabildo catedralicio aprobó con urgencia una limosna para paliar las necesidades, al estar "enfermos gran número de ellos y se mueren muchos". Concedió 400 ducados, más otra cantidad igual que aportó el gobernador del arzobispado. Todo el dinero sería destinado a la compra de alimentos.

${ }^{57}$ La ruta partió de Albolote y siguió por Colomera, Campillo, La Mancha, Pegalajar, Bejíjar, Sabiote, El Castellar, Chillana, Villamanrique, Cózar, Villafranca (de los Caballeros), Consuegra, Mora...AMT. Moriscos, 1686, registro de los 6.000 moriscos.

58 Sandoval escoltaría a 400 personas hasta Segovia, más otros 200 que iban destinados a Arévalo, otro centenar fueron dejados en Olmedo, 500 en Medina del Campo, un centenar en Tordesillas e igual número en Valladolid. Los restantes quedaban en Palencia. AMT. Moriscos, 1686, registro de los 6.000 moriscos.

59 Antonio de Hoz distribuyó 600 personas en Ávila, más otras 400 que llevaba otro comisario, cuyo nombre no quedó indicado. Los dejados en Salamanca sumaban 250, además de 
subordinado a unas pautas precisas. Los primeros en ser llamados serán los padres de familia o quienes actuaban como patriarcas de una casa. Una vez reconocidos, quedaban inscritos en un nuevo registro -efectuado por el escribano Diego Sotelo-, y borrados del antiguo. Eso sí, en el caso de no estar o faltar alguno de los componentes de esa casa, el cuadrillero responsable debía justificar su ausencia mediante un comprobante válido. ${ }^{60}$ El más inequívoco será el constituido por los recibos firmados por las autoridades de cada pueblo del trayecto, papeletas que llevaban escrito el nombre y edad, procedencia, motivo del abandono y personas que se hicieron cargo de ellos, siguiendo pautas análogas a esta: "en la villa de Campillo de Arenas quedó Isabel de España, vecina de Alhendin, muy vieja y enferma, a cargo de Sebastián García de Mateo, alcalde ordinario de dicha villa". ${ }^{61}$ Las calamidades, sin ser una afirmación categórica y a simple vista, hicieron mella en ellos, aunque la proporción de los abandonados a su suerte es poco significativa. En total, las certificaciones sumaban 148 varones y hembras, repartidos de la siguiente forma: en Pegalajar eran hospitalizados 26, otros 10 quedaron en la Manchuela (Mancha Real), 33 en Bejíjar, tres en Úbeda, uno en Baeza, 24 en Sabiote, siete en Castellar de Santiago, 13 en Chiclana (de Segura), tres en Villamanrique, 12 en Cózar, nueve en Alcubillas, uno en Argamasilla de Alba, otro en Villafranca, dos en Consuegra y el mismo número en Orgaz. De aquel total, únicamente murieron 13, de ellos cinco mujeres y los demás hombres.

Otra parte de la expedición llegó al mando de Alonso López de Obregón. Los recontaban antes de integrarse en las partidas de Sandoval y Hoz y su distribución provocó muchísimos problemas a la hora de mantener los agrupamientos familiares y hacer equivalentes ambas cuadrillas. Tanto es así que Sandoval, ya de camino, tuvo que detenerse en Olías para incluir a varias personas procedentes de la partida mandada por el otro capitán. El total del grupo sumó 1.657 individuos, cuya procedencia queda reflejada en el cuadro I.

Cuadro I.- Procedencia de los moriscos conducidos por Alonso de Sandoval. ${ }^{62}$

\begin{tabular}{lllc}
\hline Cuadrillero & \multicolumn{1}{c}{ Procedencia } & Número \\
\hline Diego de Córdoba & Monachil & & 326 \\
Rodrigo de la Torre & Los Guájares & & 307 \\
Alonso de Gros & Cogollos de la Vega & & 242 \\
Juan Lázaro & Pinillos de Guájar & 143 & \\
Alonso de Padilla & Dúdar & 141 & \\
\hline
\end{tabular}

600 asignados con anterioridad; mientras a Fuentesaúco llegaba un centenar, más 200 fueron distribuidos, por mitad, entre Toro y Zamora. La partida de Sandoval llegó a Segovia, donde dejó a 600, más 150 en Arévalo, 650 en Medina del Campo, 600 en Valladolid y 100 en Palencia. AMT. Moriscos, leg. 1686, expediente de la llegada de 1.500 moriscos.

${ }^{60}$ La orden manuscrita entregada a Sandoval y Hoz contiene ocho puntos, y en el tercero hay una alusión a los cuadrilleros moriscos encargados de entregar el pan del condumio diario a sus paisanos más pobres. Evitarían que quedasen desperdigados y controlarían la vanguardia y retaguardia, ejerciendo mayor vigilancia sobre los jóvenes, que fueron los más propensos a huir. AMT. Moriscos, leg. 1686, cuaderno 16.

61 Ibídem, Registro de los 6.000 moriscos.

${ }^{62}$ La suma total ascendió a 2.057 personas, con similar proporción de hombres y mujeres. Hubo algún caso de infiltradas de otra expedición y testimonios falsos, aunque algunos engaños eran descubiertos, como sucedió con una mujer que venía con la familia de Pedro Jahamon, traído de Monachil. 


\begin{tabular}{llc}
\hline Baltasar Enares & Güéjar & 100 \\
Bernabé Hernández & Churriana & 94 \\
Francisco Aduharen & Nívar & 82 \\
Juan Dayman & Huétor de la Vega & 52 \\
Domingo Portal & Pulianas & 46 \\
Luis Lavrei & Cájar & 42 \\
Domingo de Benavides & Huétor de Santillán & 43 \\
Juan Fernández & Cenes & 39 \\
\hline
\end{tabular}

El 26 de noviembre había preparado otro contingente en Burguillos y su mando recayó en Diego López Romero. Puesto en camino, ocurrió algo semejante a lo sucedido con los desplazados que capitaneaba Sandoval, por lo que resultó ineludible hacer un alto a fin de juntar padres con hijos, o mujeres y maridos. No hay explicación apropiada para justificar el desconcierto con que se vivió el recuento. La torpeza requirió añadir medio centenar de otro grupo, hasta alcanzar un total de 1.627 individuos. Su desigual procedencia, reflejada en el cuadro II, muestra como unos llegaban desde Granada y de su vega, otros de los pueblos de la costa, así como del valle de Lecrín y de la sierras de Güéjar y Alpujarra. ${ }^{63}$ Romero. ${ }^{64}$

Cuadro II. Procedencia de los moriscos conducidos por Diego López

\begin{tabular}{lll}
\hline Cuadrillero & Procedencia & Número \\
\hline Juan Mondragón & Granada & 396 \\
Alonso Norea & Dílar & 337 \\
Juan Ajaruz & Alhendín & 197 \\
Cristóbal de la Fuente & $\begin{array}{l}\text { Pinos de Güéjar-Pinos } \\
\text { Puente }\end{array}$ & 144 \\
Andrés Martín & Gabias & 72 \\
Mateo Cordovés & Guájaras Altas de Rey & 56 \\
Alonso Méndez & Beas de Granada & 52 \\
Juan Azama & Alhama & 49 \\
Domingo de la Cueva & $\begin{array}{l}\text { Guájaras de don Gabriel } \\
\text { y Fondón (ahora de la } \\
\text { Vega) }\end{array}$ & 46 \\
& \\
\hline
\end{tabular}

${ }^{63}$ AMT. Moriscos, 1686, registro de los 6.000 moriscos. La ruta desde Albolote puede reconstruirse con la relación de los fallecidos o enfermos. Comenzó el periplo en Colomera, continuó por Campillo, Pegalajar, La Manchuela, Bejíjar, pasaban por Baeza, Úbeda, Sabiote (donde quedaron 24 enfermos), Castellar, Villamanrique, Cózar, Alcubillas, Argamasilla de Alba, Villafranca, Consuegra y llegó hasta Orgaz.

${ }_{64}^{64}$ Los datos proceden de AHMT. Morisco, 1686, registro de los 6.000 moriscos.

65 Los de origen urbano eran tejedores de seda, tafetán, espartero, zapatero, albardero, mercader, sastre, tendero, especiero, tintorero, bodeguero, panadero, arrieros; mientras los oriundos de áreas rurales, como los de Dúdar, ejercían de hortelanos y trabajadores del campo. Figuran en esta relación individuos que mantenían sus apellidos amoriscados: Lorenzo Elcafani, Lope Jubali, Diego Elbatax, Lorenzo Aloxaja aparte de mencionar su categoría religiosa.

${ }^{66}$ Juan Álvarez Zapata, regidor de Toledo y veinticuatro en Granada, compró esa población. Martz, L. 2001. «Los toledanos y el reino de Granada de 1492 a la década de 1560», en J. Elliot, R. Kagan y G. Parker. España, Europa y el mundo atlántico: 152-176. Madrid: Marcial Pons. 


\begin{tabular}{lll}
\hline Diego Godínez & Vélez de Benaudalla & 46 \\
Juan Ebausti & Motril y Pataura & 44 \\
\multicolumn{1}{c}{ Agustín... } & Trevélez & 30 \\
& Quéntar & 26 \\
Salvador de España & Xacena (Jayena) & 26 \\
Juan Gazí & Ugíjar de la Vega & 23 \\
“ & Cúllar & 19 \\
Alonso Vélez & Padul & 14 \\
Manuel Atafriafe & La Zubia & 7 \\
No se indica & Fornes & 5 \\
“ “ & Zenes & 6 \\
Añadidos a la lista & Güéjar & 2 \\
\hline
\end{tabular}

\section{LA PARTIDA DE 685 MORISCOS}

Miguel de Eraso acampaba en Burguillos, el 6 de diciembre de 1570, a 685 hombres, mujeres y niños. Durante casi dos semanas habían permanecido en Albacete y Chinchilla, hasta que se hizo cargo de ellos el alguacil mayor Álvaro de Zúñiga, por orden del corregidor Diego de Zúñiga. ${ }^{67}$ Parecía como si su inmediatez provocase algún contagio y nadie quisiera acogerlos, y lo mismo acaeció al llegar a Toledo, hasta el punto de que una buena parte serán enviados a los pueblos de las cercanías. El repartimiento requería confeccionar una nueva lista, con los datos ya conocidos, aunque en este caso el registro final es bastante incompleto, al no indicar la profesión ni precisar la naturaleza de bastantes relacionados. Provenían, a tenor de los datos existentes, de Fiñana, en la Alpujarra suroriental, La Peza, en la cara norte de la sierra, Trevélez, en el septentrión alpujarreño, y de Alfacar, en la depresión norte de la capital.

El 4 de diciembre comenzó la adjudicación a diversos ciudadanos. El modelo siguió estas pautas: "Este dia Gabriel de Sampedro, escribano publico, rescibio a Elvira y María, hermanas, huérfanas, hijas de Miguel, vecino de Motril". Esta ficha de entrega finaliza con la firma de los receptores, algo poco usual, aunque hay numerosos huecos en blanco al respecto. ${ }^{68}$ Lo más llamativo de la nómina es que no figuran familias enteras, como sucedió en otros momentos, ya que en esta ocasión los consignatarios recibieron una sola persona, un huérfano, a lo sumo dos, y evitaron acoger a familias nucleares. Por una serie de circunstancias eran conducidos los no acomodados a unos corrales existentes en el barrio de las Covachuelas, entre ellos un alfaquí llamado Diego de Luna, instalado con su familia junto a otros 31 hombres, mujeres y niños que formaban distintos hogares. ${ }^{69}$ Los

67 AMT. Moriscos, 1686, repartimiento realizado por el corregidor de la ciudad de Toledo Diego de Zúñiga, con solo 685 oriundos de Granada, integrantes de una supuesta lista de 1.500 personas.

68 Otra referencia indica: "Miguel Navarro, platero, vecino de Toledo, a la colación de saniuste, recibió a Alonso de siete años, hijo de Luis Antorbo, vecino de farayra (sic) (Ferreira)".

${ }^{69}$ En una casa situada en la Granja, parroquia de Santiago, fueron alojadas 41 personas de diversos hogares. El cura de la parroquia de San Vicente, Luis Hurtado, tomó para trabajar con su hermano a dos jóvenes huérfanas. 
jóvenes, como ya ocurrió con otras expediciones, quedaban encomendados en calidad de sirvientes; en total, 76 chicos y 75 chicas, de edades entre siete y veinte años, aparte de un niño con tres años, quizá inscrito aquí por error, y una niña de pecho, hija de una madre de veinte años.

El traslado hasta los pueblos se hizo con cierta urgencia, a pesar de sus deplorables condiciones físicas y del escaso descanso que tuvieron después de un camino tan largo. ${ }^{70}$ La imagen paupérrima que traslucían hizo que desde el corregimiento de Toledo fuesen compelidas las autoridades de los lugares de destino para que efectuasen una recepción inmediata. El corregidor exigió que trajesen carros y bestias para remediar su deterioro físico, aparte de pretender que no falleciesen antes de llegar a la localidad receptora, ya que las cédulas reales insistían mucho en prestarles auxilio y castigaban el incumplimiento. ${ }^{71}$ La suerte no cambió para la mayoría al llegar a los lugares de destinos. Allí soportaban nuevas pesadumbres, como denuncia un documento de fecha 22 de marzo de 1571, donde figuran los repartidos por diferentes pueblos de la provincia y, al lado, las cifras de sobrevivientes.

El número tan relevante de fallecidos llegó a conocimiento de la realeza, sin que hubiese un pronunciamiento condenatorio sobre ello, quizá pensando que, a mayor número de fallecidos, el problema disminuía. La escasez alimentaria provocada por la falta de dinero para pagar el avituallamiento será el principal causante de tantas víctimas. Esa problemática creció al no conseguir un trabajo remunerado y escasear la ayuda caritativa de sus convecinos, debido al rechazo xenófobo y religioso que causaban. En el cuadro III queda reflejada la alta mortalidad, aunque cabe argumentar que el porcentaje no era distinto al de los "avecindados" en la ciudad e ingresados en el hospital de Tavera. ${ }^{72}$

Cuadro III.- Moriscos asentados en la jurisdicción toledana, entre marzo-abril de 1571

\begin{tabular}{lcrlrc}
\hline Localidad & Personas & Fallecidos & Localidad & Personas & Fallecidos \\
\hline Alameda & 14 & Sin datos & Albala & 13 & Sin datos \\
Ajofrín & 57 & 31 & Añover & 23 & s/d \\
Arisgotas & 11 & & Arcicóllar & 13 & \\
Burguillos & 15 & 7 & Burujón & 18 & \\
Camarena & 42 & & Cabañas & 16 & 9 \\
Casalgordo & 6 & 2 & Cobeja & 16 & \\
Chozas & 26 & & Escalonilla & 26 & \\
Lominchar & 20 & 4 & Manzaneque & 16 & 14 \\
Mascaraque & 16 & 1 & Mazarambroz & 33 & 8 \\
Mocejón & 18 & 5 & Nambroca & 25 & 8 \\
\hline
\end{tabular}

70 AMT. Moriscos, 1686. Registro de moriscos que había en Toledo y los pueblos de su jurisdicción, tras el repartimiento realizado en cumplimiento de una real cédula de Felipe II, marzo y abril de 1571. No figuran en el cuadro aquellos que llegaron a Yeles en mayo del año 1573.

${ }^{71}$ Los bastimentos disponibles eran escasos; así, en Cabañas recibieron 30 fanegas de pan cocido, 12 ovejas, 24 quesos y 1.213 trece panes con un peso de 96 arrobas, para repartir entre 685 personas. AMT. Moriscos, 1686, reparto de 685 moriscos.

72 Zamorano Rodríguez, M. L. 1997. El hospital de San Juan Bautista de Toledo durante el siglo XVI: 236. Toledo: Diputación. Sobre los efectos tan aciagos que soportaron hay un dato revelador. Así, de los 635 enviados a los pueblos solo sobrevivían 350, es decir, un 45\%. Martz, L. 2009: 95-96. Por contrastar esas cifras con los alistados en Toledo en abril de 1571, de los 1.875 llegados quedaban vivos 1.150; esto es, había muerto un $63 \%$. 


\begin{tabular}{|c|c|c|c|c|c|}
\hline Pantoja & 44 & 4 & Polán & 10 & 1 \\
\hline Recas & 12 & & Rielves & 18 & \\
\hline Totanés & 14 & & Yuncos & 12 & \\
\hline Yuncler & 16 & & Yunclillos & 43 & \\
\hline Villamiel & 33 & & Villaminaya & 16 & \\
\hline
\end{tabular}

Los valores del cuadro, por otro lado, muestran como el poblamiento morisco no fue numeroso en áreas rurales cercanas a la ciudad, aunque su total resulta significativo. La excepción más palpable corresponde a poblaciones de la comarca de la Sagra, entre ellas Illescas, donde estuvieron censados 122 moriscos, allá por el año 1571. Además, hubo otras 25 casas en Borox, y un impreciso número de hogares, no más de dos decenas, en las poblaciones como Villaseca de la Sagra, Yeles, Añover o Mocejón, todas en la misma comarca. ${ }^{73}$ A Mocejón llegó durante varios años una notable emigración pendular de trabajadores del campo y hortelanos para trabajar en las fincas de Velilla e Higares, oriundos de las parroquias toledanas de Santiago e Isidoro. ${ }^{74}$ De trasiegos parecidos hay referencias a partir del año 1578, entonces en sentido inverso al producirse un movimiento migratorio de los pueblos a la ciudad.

\section{LOS REGISTRADOS EN DICIEMBRE DE 1570}

Bajo las órdenes de un tal Fernando de Ágreda llegaron 770 granadinos, el 9 de diciembre de 1570, oriundos de Alpandeire, Júzcar, Benalauria, Benarrabá, Jubrique, Istán, Benaoján. Faraján, Benadalid y Montejaque, poblaciones todas ellas de la Serranía de Ronda. La orden real instaba a repartir a medio millar por los lugares de los Montes de Toledo, algo nuevo hasta entonces, como se induce de una información posterior y con una conservación deficiente. El resto debía entregarse a toledanos, bien como asalariados o en calidad de esclavos, una condición de dificultosa precisión al no explicitarse en las minutas de transmisión.

Una nueva expedición, dirigida por un tal Bartolomé Pérez, arribó el 5 de diciembre. Sumaba 1.587 personas, de origen heterogéneo aunque naturales de lugares cercanos a Granada. En esa lista figuraban 146 nativos de Dúdar, 45 de Huétor Santillán, 64 de Nívar, 25 de Cájar, 33 de Cenes, 64 de Huétor de la Vega, 64; de Cogollos venían 228; ${ }^{75}$ de Pinos de Güéjar, 109; Pinos del Rey, 113, Guájaras Altas del Rey, 56, Guájaras de Gabriel y Alfonsón,46, Pulianas,44; mientras que 120 dijeron ser naturales de Dílar, cinco de Fornes, 16 de Xayena, ocho de Cenes, cuatro procedían de Pinillos y el mismo número de Quéntar. Los naturales de Motril eran solo siete, mientras los naturales de Cúllar sumaban 19. La relación nominativa que se hizo tiene defectos insoslayables, algo que contrasta con las pautas tan precisas seguidas en la confección de otros registros, lo cual confirma la ausencia en este momento del escribano Diego Sotelo. Los errores quedan patentes en la suma de cada folio, e igual pasa con el cálculo estimativo del total, donde hay bastantes imprecisiones, como figurar el nombre del cabeza de familia y no el de los demás miembros del hogar. La designación queda sobreentendida con palabras como "tiene mujer", "y un hijo", "tiene cinco hijos, el

73 Permanecían 26 individuos vivos en Yeles, allá por el mes de mayo de 1573. AMT. Moriscos, 1687-88, registro de los moriscos de Yeles.

74 Magán, J. M. y Sánchez, R. 1993: 26-31 con referencias imprecisas sobre su composición.

75 La estructura de cada hogar variaba entre tres y cinco hijos por familia. 
mayor de catorce años". Frente a esa falta de rigor en la identificación de los arribados, está la precisión empleada en los 131 que quedaban en el camino con múltiples enfermedades. ${ }^{76}$

En los meses siguientes recalaban otros grupos. No es posible cuantificar con exactitud los moriscos que vinieron en alguna de esas partidas al estar las listas muy fragmentadas. No contienen referencias precisas sobre la procedencia y destino. Una lista bastante completa es la formada por 198 hombres, naturales de Granada y de varias localidades de la vega y el litoral, entre ellas Jayena, Gójar, Monachil, Churriana, Dílar, Fornes, Cúllar, Pinillos, Cenes, Motril y Quéntar. En otro cuadernillo fueron más meticulosos los escribientes, como el que contiene el nombre de 17, llegados desde Écija y Carmona, en abril de 1571, y que fueron acampados en la ciudad, concretamente a la entrada de la ermita de San Leonardo, junto al pósito. Hasta aquí acudía un escribano público para tomarles una declaración inusual: hacer constar que el capitán Sancho de Mora les había dado un trato esmerado. ¿Había alguna queja de otros grupos y por eso se presentó el fedatario? A simple vista, es extraño el requerimiento a no ser que las voces de la tragedia hubiesen hecho impacto en altas instancias y los cuadrilleros necesitasen certificar que no infligían castigos y cumplían las pragmáticas a rajatabla. La verdad es que la sensibilización fue escasa y así lo evidencia la documentación. Por el contrario, los moriscos estuvieron sometidos a un estricto control, hasta el punto que los avecindados en Toledo estaban obligados a presentarse cada quince días ante el corregidor. En el caso de incumplir esa orden serán castigados con multas y pudieron ser sentenciados a muerte cuando salían de la ciudad sin un pasaporte de tránsito. La presión arreció cuando arribó un grupo de monfíes, liderados por un tal Juan Retal, al estar considerados muy peligrosos. ${ }^{77}$

En los primeros días del mes de mayo del año 1571 acampó otro grupo en Burguillos. ${ }^{78}$ Por el alistamiento, demorados hasta el 11 de junio, se sabe que venían de distintas localidades granadinas y sumaban 65, mujeres mayoritariamente. Permanecieron poco tiempo y fueron conducidas hasta los lugares donde se hallaban sus maridos o padres, Cebreros, Alcalá y Ocaña. El escribano realizó otro alistamiento en los primeros días de junio, donde figuran 44 personas, en su mayor parte hombres, acogidos en la ciudad. ${ }^{79}$ Hay una nómina más, confeccionada el 12 de junio, con 193 personas, la mayoría hombres, calificados como "rebelados", y otros 68, originarios de Baza. Todos serán remitidos a Alcalá bajo la custodia del capitán Francisco de Avendaño. En tanto que unos salían, llegaban otros. Así, arribaron 53 originarios de Baza y Guadix, de paso porque serían reexpedidos a Alcalá, mientras una cuadrilla de 186, procedentes de

76 En Sabiote quedaron 34, AMT. Moriscos, 1686, registro de los 6.000 moriscos. Al instalarse en Toledo, lo harán en corrales. Hubo 19 familias alojadas en el barrio de la Granja, de las cuales seis eran matrimonios completos, dos mujeres solitarias, más un hombre y su hijo, y una viuda acompañada de su hijo.

77 Declaración del procurador del regidor Juan de Silva, AMT. Moriscos, 1686, expediente iniciado por copia de una carta de Felipe II al duque de Arcos para que traiga a Toledo a 16 moriscos desde Écija y Carmona.

78 En esa expedición aparecen 11 denominados moriscos leales, ocasionalmente llamados cristianos viejos, los cuales gozaron de prerrogativas que no tuvieron los sublevados. En febrero de 1570, un tal Alonso Rodríguez Afín, curtidor, avecindado en la ciudad, debía ser tratado de forma especial, según una orden real, sin molestarle ni tomar sus bienes al ser cristiano viejo. AMT. Moriscos, 1686, registro de los 624 moriscos traídos por Rodrigo de Monsalve.

${ }^{79}$ Los asentados en Ocaña eran 279, a decir de Moreno Díaz, 2009: 111, cuadro 14. 
Almuñécar, etiquetados como rebelados, serán albergados en Toledo y Yeles, bajo estrictas medidas de vigilancia.

A finales de mayo, los alguaciles Juan de Aguilera y Alonso Sánchez trajeron 225 hombres y mujeres procedentes de Baza. Fueron muy repartidos y 50 quedaron en Toledo, otros tantos llevaron los cuadrilleros a Valladolid, un número similar quedó en Alcalá y el resto iban hasta Membrilla. El 23 de junio arribaron 165 más, y otros 60 dos días después, todos oriundos de Guadix. Unos y otros fueron concentrados en el mesón de Abrevadero y repartidos con mucha prontitud. La lista elaborada evidencia que en Toledo quedaron 32, a Esquivias llevaron a 25, otros 20 fueron a Magán, más 30 a Novés y 24 serían conducidos hasta Escalonilla. En el mismo mesón, el día 10 de agosto, eran agrupados otros 42 granadinos, naturales de Cortes, en pésimas condiciones de salud. ${ }^{80}$ Las autoridades decidieron unirlos a un grupo procedente de Fiñana para evitar su fallecimiento y eran llevados a Olías, Argés, Azaña, Bargas y Magán, en las cercanías de Toledo, de forma temporal si antes no morían. ${ }^{81}$

El alguacil Juan Ortiz llegaba con sólo 15 individuos días después. Formaban parte de una conciliación familiar, cuya expedición principal quedó en Almagro; acomodo que volvió a repetirse con otros desplazados durante todo el año 1574. En 1576 arribó otra cuadrilla procedente del condado de Santisteban, de las Navas y de Castellar. Eran mayormente hombres y recalaban aquí por un error en la interpretación de las disposiciones, equivoco que intentó modificar el corregidor Gutiérrez Tello con su reenvío a las localidades donde estaban sus familias, al ser evidente que con ellos no se respetaron las instrucciones de Pedro de Deza, presidente de la chancillería de Granada, relativas a evitar las separaciones matrimoniales. ${ }^{82}$ Este tipo de agrupamientos será muy frecuente en meses posteriores, si bien conllevó un importante desembolso económico para los retornados, al tener que hacer frente al coste de una probanza para demostrar no ser salteadores. Además, debieron pagar la fianza de seguridad. ${ }^{83}$

El reagrupamiento de las familias separadas tuvo visos de mayor fluidez entre los años 1577 y 1580. Al menos, hay constancia de que un grupo procedente de Estepa, con 119 individuos, matrimonios con hijos, llegaba para reunirse con otros parientes ya asentados en diversos pueblos toledanos. Se desconoce dónde quedaron establecidos. La llegada de una nueva partida, en número poco relevante, durante julio de 1578, hizo que fueran expuestos en la explanada del hospital del Cardenal para que los reclamasen sus parientes. Del año 1579 es una nómina de moriscos antequeranos, transitoriamente acogidos en la localidad sevillana de Marchena, que iban destinados a Alcalá y al pueblo de Escalona. A partir de esta fecha, ante la escasez de recursos alimenticios que padeció el reino

${ }^{80}$ Entre los registrados aparece un tal Diego Vaca, labrador, con su mujer y dos hijos, más una criada. Los vecinos de algunos pueblos se quejaban de no poder alimentarlos, y su destino, ante la imposibilidad de trabajar, era morir de hambre.

${ }_{81}$ AMT. Moriscos, legajo 1687.

${ }^{82}$ La cédula real para permanecer en el condado llegó con retraso. En el leg. 1687-88, está el expediente iniciado por la pragmática de 4 de marzo de 1576, con la lista de quienes provenían del Adelantamiento de Cazorla y condado de Santisteban. Los conducidos a Baeza y Cazorla fueron tratados como si fuesen esclavos, sobre todo las mujeres y niños. AMT. Morisco, leg.1689, cuadernillo 4.

${ }^{83}$ En el alistamiento figura una tal Ana de Burgos, algebrista, procedente de Pastrana, casada. Llegó a Toledo, en octubre de 1603, para ejercer su oficio al disponer de una carta de examen refrendada por los médicos de la cámara real. AMT. Moriscos, leg. 1688. 
de Toledo por la crisis de subsistencia, se organizaban varios desplazamientos a zonas levantinas, Murcia entre ellas. Iban a trabajar temporalmente, con una licencia de tránsito de no más de cuarenta días, en la "cría de la seda". ${ }^{84}$ Un apunte conclusivo para finalizar. La mayor parte de los moriscos llegados a Toledo hasta finales de la década de los setenta lo hicieron de paso; tampoco conformaban partidas numerosas y unas quedaron en la ciudad, otras serían conducidas a los pueblos aledaños y solo algunos pocos iban a quedar registrados en puntos más distantes.

\section{LOS MORISCOS DE LAS MATRÍCULAS MUNICIPALES}

El 22 de marzo de 1571, el corregidor Hernán Velázquez comenzó a confeccionar un nuevo alistamiento de los cristianos nuevos granadinos asentados en la ciudad. Los concentró en los aledaños de los hospitales de San Juan Bautista y Santa Cruz, registrándose 1.127, mientras otros 52 no acudían al estar enfermos o impedidos, entre ellos una mujer que acababa de parir. ${ }^{85}$ La nómina es aprovechable para ahondar en detalles sobre ellos, a pesar de lo cual presenta tres lagunas de cierta envergadura. En primer lugar no consta la colación parroquial donde residían, solo es identificado el cabeza de familia y, en un tercer lugar, no hay datos sobre las personas que formaban el grupo doméstico.

El corregidor Gutiérrez Tello, con la estimable ayuda del escribano Pedro de Villarreal, efectuó un nuevo control el año 1573. De él se conserva un atado formado por casi dos centenares de folios, horadados, cuyo contenido, a riesgo de simplificar bastante sus características externas, tiene secuencias precisas, entre ellas indica la parroquia de su morada, su nombre, oficio, edad, origen, aparte de perfilar un somero retrato del aspecto físico en función de ciertas señales visibles. ${ }^{86}$ Aquel boceto abarca rasgos definitorios para componer esa instantánea, con detalles como "señalado en la cabeza de tiña", definir el color de la piel y ojos, "morena de rostro y ojos azules", "ojos leonados y alto de cuerpo", hasta apariencias tan perceptibles como ser "tuerto del ojo izquierdo, con señales de viruela en el rostro.", o llevar "una cruz en el cuerno de la frente del lado izquierdo, es de una pedrada". Detalles interesantes, sin duda, a la hora de entresacar los atributos físicos o características fisiológicas, algo que escapa del objetivo de este artículo.

El corregidor Fadrique Portocarrero hará una nueva pesquisa allá por los años 1580-1582. ${ }^{87}$ En la información hay omisiones sustanciales y fallos debido a que

84 Ibídem, expediente iniciado en 1587-88. También hay un proceso seguido contra el morisco Diego Hernández Marín, arriero, que fue apresado en Marjaliza por haber salido a más de cinco leguas de la ciudad sin licencia ni pasaporte. Quedó en libertad porque ambos documentos los presentó su defensor.

${ }^{85}$ AMT. Moriscos, leg. 1686. Registro de los moriscos que desde el 10 de marzo de 1571 llegaron a Toledo enviados desde el reino de Granada por el duque de Arcos y que fueron repartidos por la ciudad y los lugares de su jurisdicción por su corregidor Hernán Velázquez. 175 hojas. Fecha mayo 10 de 1571 hasta diciembre de 1575.

${ }^{86}$ Analizadas por Vincent, B. 1985. Andalucía en la Edad Moderna: economía y sociedad: 306 y ss. Granada: Diputación. Otros trabajos, Prieto Bernabé, J. M. 1987. «Aproximación a las características antropológicas de la minoría morisca asentada en Pastrana en el último tercio del siglo XVI», Wad-al-Hayara, 14: 355-362, y Vincent, B. 1998. "¿Qué aspecto físico tenían los moriscos», II Coloquios de Historia de Andalucía, II: 335-340. Córdoba: C.A.M.P.

87 El motivo para realizar la matrícula es algo confuso, tal vez se hizo para proveer de bastimentos a los granadinos avecindados en la ciudad, al ser aquellos años de notable esterilidad. 
intervinieron diversas manos en su preparación ${ }^{88}$, aparte de reproducir registros de otros cuadernillos como si fuesen originales, en concreto los realizados en el mes de noviembre. La información contenida en las primeras 532 referencias es útil para situar dónde habitaban o conocer los sectores labores donde trabajaban. Las parroquias de mayor asentamiento eran las de Isidoro y Santiago, con un $71 \%$ del total; seguida de la de Santo Tomé, con apenas un $7 \%$, la de San Andrés, San Miguel y San Martín, que mantuvieron valores de entre un 3,7\% y un 3,3\%. La presencia en otros distritos eclesiásticos no superó el $2 \%$, como sucedió en santa Leocadia, Magdalena o en las parroquialidades de los santos Cebrián, Nicolás, Justo y Pastor, mientras solo tres quedaron en la colación de la capilla de san Pedro.

En lo que concierne a la situación laboral, hay 398 registros donde claramente especificada. La muestra evidencia que un $47 \%$ trabajó en el sector primario, un $24 \%$ lo hizo en el secundario y un $28 \%$ en el terciario. Quedan referencias sobre la presencia de varios esclavos y bastantes manumitidos, estos últimos con las imborrables marcas de cautivo en su cara. Figura entre ellos un tal Diego de Mendoza, de 60 años, incapacitado para trabajar por carecer de ambas manos, cuyo sustento lo obtuvo su mujer, con 40 años, y una hija de 14.

\section{LOS PODERDANTES MORISCOS}

El escribano del número Blas Hurtado recibió un encargo bastante especial, con fecha 18 de noviembre de 1589. Era escogido para protocolizar unos poderes por un grupo de cristianos nuevos, un encargo que ejecutaban tres de sus congéneres llamados Diego de Salcedo, Alonso Hernández y Sebastián López. ${ }^{89}$ ¿Con qué propósito se otorgaba? Su validez era muy amplia, en tanto en cuanto podían utilizarse para proseguir demandas en los Consejos, Chancillerías y Audiencia arzobispal, aunque esa imprecisión en el uso impide saber cuál era el destino real del documento. Caben cuatro suposiciones al respecto: los poderdantes utilizarían esos poderes para ajustar una derrama fiscal, iban a utilizarlos para obtener licencias de desplazamientos y permisos para juntar familias separadas, podían usarlos para acordar fianzas de resguardo, o perseguían la obtención de alguna prerrogativa por ser "moriscos de paces". ${ }^{0}$ La amplitud de finalidades hace que aquel interrogante sea casi incontestable; sí es plausible asegurar que los ejecutores del encargo eran alamines de la comunidad, elegidos como garantistas del compromiso y negociadores con el escribano de sus honorarios. ${ }^{91}$ Gente importante aunque con derechos limitados, por lo que

Boeglin, M. 2007. «Entre la resistencia y la política de asimilación y la fabulación: el "levantamiento" de los moriscos andaluces de 1580». Historia, Instituciones y Documentos, 34: 29-55, presume que fueron una vanguardia oculta en los momentos previos a la invasión de Portugal.

${ }^{88} \mathrm{Ni}$ la residencia ni la profesión figuran, como queda patente entre los folios 16 y 32 y vuelve a repetirse entre los números 64 y 77.

89 AHPT. Protocolo 2208, f. 269, año 1589, Blas Hurtado. Firmaba solo un $22 \%$ de los poderdantes, valor porcentual similar al recogido por Dadson, T. 2007: 766.

${ }^{90}$ En el año 1587 pagaron sumas importantes por conseguir licencias para trajinar, según Moreno Díaz, 2009: 301. Las imposiciones anuales que los moriscos negociaban con el conde de Orgaz y con el rey fueron objeto de interés por Sánchez Romeralo, J. 1984. «El Conde de Orgaz, protector de los morisco», La España medieval, IV: II, 900-916. Solicitudes de pasaporte en AHPT. Protocolo, 1881, f. 201, año 1583, Jerónimo Castellano.

${ }^{91}$ Referencias de los alamines, en Carrasco, 2009: 185. 
requirieron la aquiescencia del entonces alcalde mayor doctor Quiñones para poder otorgar el instrumento protocolario. Lo chocante es que no dejasen pistas sobre su residencia ni de su profesión.

El escribano hizo la llamada minuta yendo con la péñola hasta las parroquias de Santiago del Arrabal y San Isidoro. ${ }^{92}$ Después, redactó los poderes en su escribanía y asentó el nombre de 402 hombres en el papel, con constancia expresa del oficio de 382, un valor numérico que permite saber cómo se ganaban la vida aquellos granadinos después de transcurrir una veintena de años fuera de su tierra. El dato, por otro lado, permite hacer analogías con otros fondos documentales, en este caso, con un "censo". Mejor dicho, un recuento de los feligreses moriscos efectuado por el párroco de San Isidoro, Luis de Vinuesa, con información sobre dónde y cuántos estaban alojados en cada casa, su edad y ocupación. El presbítero siguió las instrucciones emanadas de las constituciones sinodales, en especial las más afines a las normas de evangelización de esa minoría convertida, y las del prelado Gaspar de Quiroga orientadas al cumplimiento de los preceptos religiosos de su nueva fe. Resultaba fácil presentir que muchos de esos "cristianos nuevos" habían abrazado la religión sin verdadera convicción y con criterios de notable laxitud..$^{93}$

Del cotejo de los datos puede efectuarse algún que otro corolario, como es dibujar el arco profesional. Según la matrícula del párroco, más o menos el $50 \%$ de los asentados ejercía en el sector primario, como trabajadores del campo y hortelanos. ${ }^{94}$ Una preponderancia similar quedó constatada en el cotejo con los poderes de Blas Hurtado, al aparecer 125 como "asalariados", más cuatro labradores y 13 hortelanos. Totalmente diferentes son las proporciones a la hora de evaluar el peso que tuvieron los tratantes. En el documento del cura Vinuesa no hay ninguno; mientras se cuentan hasta 13 en las escrituras de Hurtado. ${ }^{95}$ No es fácil desemparejar la condición de tratante y la de mercader en aquel tiempo. Uno compraba caballerías, granos y otros productos por menudo, cuya venta realizaba por los pueblos, algo similar al ejercicio de la arriería. El mercader actuaba con mayor sedentarismo, sin apenas moverse de la tienda emplazada en el perímetro ciudadano. Así que, al buscar una explicación de esa discordancia, la más plausible es que quienes dispusieron de una holgada situación económica, de un pequeño capital en animales, mercaderías y deudas, rechazaron vivir en la colación regida por Vinuesa, una de las más pobres del ámbito urbano. Disfrutaron, empero, de

92 Tapia, S. de. 1994. "Una minoría urbana mal conocida: los moriscos "convertidos" en Castilla la Vieja», en J. Hinojosa y J. Pradells Nadal (eds.), 1490: en el umbral de la Modernidad. El Mediterráneo europeo y las ciudades en el tránsito de los siglos XV-XVI: 459, Valencia: Generalitat. En Ávila trabajaron dos escribanos moriscos en las últimas décadas del siglo XVI, convirtiéndose en los fedatarios por excelencia de sus correligionarios. Hurtado no procedía de un linaje morisco, si bien pudo tener un entronque converso.

93 Rodríguez, H. 1981: 521-542. Vincent, B. 1996. «La disidencia morisca», Disidentes, heterodoxos y marginados en la Historia: 112. Salamanca: Universidad.

94 Rodríguez, H. 1981: 536. Carrasco, R. 2009: 79. Los oficios más habituales eran tratante, aguador, albañil, buñolero, hortelanos y jornaleros, comúnmente denominados trabajadores. Para hacer comparaciones del arco ocupacional en una ciudad castellana, Tapia, S. de, 1990, «Fiscalidad y actividades económicas de los mudéjares de Ávila en el siglo XV»: 87-104. V Simposio Internacional de Mudejarismo, Teruel: Instituto de Estudios Turolenses.

95 Hay varias referencias en AHPT. Protocolo 2630, f. 436, año 1601, escribano Tomé de Segura. Sobre las colaciones donde vivían los tratantes de fruta, aceitunas y zumaque, en protocolo 2417, fs. 663 y 747, escribano Pedro de Galdo. 
mayor prestigio que los trabajadores del campo, querían mejorar su imagen personal y podían permitirse disfrutar de mejores comodidades. Una razón primordial para abandonar un barrio tan suburbano como la Antequeruela o la Granja. No vivieron tampoco en ninguna casa de la parroquia de San Isidoro los 8 mercaderes que figuran en los poderes, al desear vivir intramuros para transmitir una imagen de éxito empresarial y social. ${ }^{96}$

En el quehacer diario de estos moriscos queda un tercer lugar para los herreros y arrieros, mientras los alfareros, carpinteros, ${ }^{97}$ zapateros, tejeros y panaderos figuraban en puestos de menor categoría. ${ }^{98}$ No es fortuito decir que los tres tenderos firmantes de los poderes vendían artículos de poco valor por las calles, los llamados géneros "de menudo", acarreados en una cesta grande colgada al cuello. Los aceiteros, por destacar otras peculiaridades, presentan valores muy semejantes en ambas fuentes. Y lo mismo sucede con los alfareros, buñoleros, herreros, maestros del arte de la seda, panaderos y sastres. ${ }^{99}$ Al hilo de lo dicho, la matricula efectuada por el párroco contiene profesiones como la de basurero, bonetero y bodeguero. Ninguna figura en los poderes, aunque pudo haber moriscos dedicados a ellos. La omisión estaría supeditada a una razón económica, ya que quienes estaban afincados en la circunscripción religiosa de San Isidoro tuvieron escasa fortuna y poseyeron un limitado espíritu emprendedor. Ante tales limitaciones, dirigieron su preferencia a alquilar la fuerza de su trabajo en faenas agrícolas, y otras labores de dureza similar, en vez de hacerlo en las que entrañaban movilidad y riesgo. Los basureros o boneteros no necesitaban licencias de tránsito ni buscaban rebajas fiscales por sus "utilidades". En el caso de los tintoreros, profesión que requería habilidad y que entrañaba una dureza más que notable, ambas fuentes traslucen una escasa preferencia por estos moriscos, todo lo contrario a la de tejedor y bruñidor, que ejecutaban con mucha pericia. ${ }^{100}$ En este mismo orden de cosas es llamativa la presencia de un naipero, un tal Miguel Hernández, con hogar en la parroquia de Santiago, dedicado a la venta de barajas,

${ }^{96}$ Algunos moriscos llegaron a acumular una sustancial fortuna, tanto en capital circulante como créditos, situación que ratifica Moreno Díaz, F. J. 2009: 251. El matrimonio morisco formado por Diego de Molina y María de Baeza hizo una declaración de sus bienes, en 1609, antes de ser expulsados. Tenían 100 ducados en efectivo, quizá de los bienes urbanos vendidos, más collares, manillas, zarcillos, valonas, tocas y numerosos pañuelos con puntas de oro. AHPT. Protocolo 2707, f. 691, año 1609, Juan Gabriel.

97 Los carpinteros moriscos estaban considerados muy hábiles y no ponían obstáculos por salir de la ciudad a trabajar, como hizo un tal Diego Ricote, que levantó en Argés una casa al heredero Pedro López de Loaisa. AHPT. Protocolo, 2819, f. 21, año 1604, Miguel de la Jara.

98 En los poderes no figuran mujeres, aunque muchas ejercían ocupaciones remuneradas, como consta en una obligación suscrita por el matrimonio formado por Baltasar Hernández y María Hernández. Ella figura como "maestra", presumiblemente de hacer medias de seda, AHPT. Protocolo 64, año 1604, escribano Lorenzo de Tapia. En otro documento, protocolo 1806, f. 378, relacionado con los moriscos alistados en Navahermosa, figuran las mujeres confeccionando labores artesanales. AMT. Moriscos, legajo 1687, aparece una tal Mari Rodríguez, "que texe, labra y cose", mientras en el cuaderno número 15 hay una laborante de "hacer seda de ingenio" llamada Mencía Enríquez.

${ }^{99}$ Algunos aceiteros llegaron a tener una importante suficiencia económica. Señal de ello es un tal Juan, que pagó en plata el valor de la cosecha de aceituna a varios propietarios. AHPT. Protocolo 2554, f. 157v. año 1597, Miguel Díaz.

100 El abandono de esos trabajos rigurosos, en Dadson, T. 2007: 155. 
cartas muy utilizadas para juego de envite y distribuidas por un monopolio intitulado "estanco de los naipes". 101

Cuadro IV.- Profesión de los poderdantes moriscos. ${ }^{102}$

\begin{tabular}{|c|c|c|c|c|c|}
\hline Aceitero & 3 & Espartero & 2 & Tejero & 9 \\
\hline Albardero & 2 & Especiero & 2 & Tendero & 3 \\
\hline Alfarero & 13 & Herrero & 15 & Teñidor & 1 \\
\hline Arriero & 14 & Hortelano & 13 & Trabajador & 124 \\
\hline Azacán & 8 & Jalmero $^{103}$ & 2 & Tratante & 38 \\
\hline Barbero & 1 & Labrador & 4 & Tratante aceite & 1 \\
\hline Bruñidor & 3 & $\begin{array}{l}\text { Maestro } \\
\text { arte seda }\end{array}$ & 7 & $\begin{array}{l}\text { Tintorero } \\
\text { holandillas }\end{array}$ & 1 \\
\hline $\begin{array}{l}\text { Bruñidor } \\
\text { holandillas }\end{array}$ & 1 & Mercader seda & 8 & Tintorero paños & 1 \\
\hline Buñolero & 5 & $\begin{array}{l}\text { Mercader } \\
\text { especias }\end{array}$ & 8 & Tintorero seda & 4 \\
\hline Candelero & 1 & Mercader & 3 & Tallarola $^{104}$ & 1 \\
\hline Carpintero & 12 & Mercero & 1 & Tornero & 1 \\
\hline Carbonero & 1 & Mesonero & 1 & Verdurero $^{105}$ & 1 \\
\hline Cerrajero & 1 & Naipero & 1 & Zapatero & 13 \\
\hline Confitero & 1 & Panadero & 8 & Sin oficio & 20 \\
\hline Criado & 1 & Sastre & 6 & \multirow{3}{*}{ Total } & \multirow{3}{*}{402} \\
\hline Cuchillero & 6 & $\begin{array}{l}\text { Tejedor } \\
\text { terciopelo }\end{array}$ & 4 & & \\
\hline Curtidor & 1 & $\begin{array}{l}\text { Tejedor } \\
\text { damasco }\end{array}$ & 1 & & \\
\hline
\end{tabular}

De algunos otorgantes de los poderes no hay una información veraz sobre su oficio; por ejemplo, los arrieros, debido a la versatilidad de su actividad, pudieron compaginar esa y otra ocupación, aunque tanto trajinería como arriería eran ocupaciones muy extendidas entre la comunidad morisca. Hasta tal punto que un protocolo, fechado el año 1597, dejó recogida la colaboración de 37 trajineros, todos residentes en la ciudad, en la campaña de Aragón del año 1591, compensándoles con una sustancial rebaja en el servicio de 200.000 ducados que debían pagar. Los moriscos toledanos, en reciprocidad, abonaban únicamente la mitad de la suma estimada. ${ }^{106}$

La ubicación domiciliaria de los clientes de Hurtado permite abrir el arco de deducciones y entresacar dos posibilidades. Una es de tipo residencial, mientras la

101 El cargo y data del administrador de las barajas, en AHPT. Protocolo 2150, f. 731, año 1609, Álvaro Pérez de las Cuentas.

${ }_{102}$ Los datos proceden de AHPT. Protocolo, 2208, f. 269 y ss. año 1589, Blas Hurtado.

103 Confeccionaban una especie de albardón pequeño, usado para andar a caballo, en los viajes o salir a cazar.

${ }^{104}$ Fabricantes de cuchillas muy finas, utilizadas para cortar los bucles de la trama y el pelo en los telares de terciopelo.

105 Su ocupación principal pudo ser verdulero o verdugalero.

106 AHPT. Protocolo, 2463, f. 816, año 1597, escribano Pedro Ordóñez de Sosa. La presencia de estos acarreadores en la campaña portuguesa de 1580, en Gómez Vozmediano, M. 2000: 121. 
otra es económica y resulta más dificultosa de puntualizar. En relación a la primera ya se refirió con anterioridad que los moriscos llegados entre los meses de noviembre y diciembre del año 1570 quedaron alojados en la colación de San Isidoro y Santiago del Arrabal. En este último distrito hubo una barriada designada con el apelativo Antequeruela por apiñarse en ella sus domicilios. ${ }^{107}$ En la otra colación abundaron los corrales y casas de vecinos y en ellos fueron alojados numerosos moriscos. Con el paso de los años, vivir en una colación o en otra tuvo una directa correlación con el coste del alquiler y de las posibilidades para acceder a la propiedad, ambas cosas más onerosas en las parroquias no suburbanas. EI hacinamiento, por otro lado y al hilo de las deducciones, en San Isidoro mantendrá estrecha conexión con las medidas de control y vigilancia establecidas por las autoridades civiles y eclesiásticas. Con el paso de los años, un indeterminado número de las familias moriscas optó por asimilarse, una iniciativa más anhelada en tanto en cuanto gozaban de mayor desahogo económico, y lo consiguieron trasladándose a feligresías como Santo Tomé, San Lorenzo, ocupada por tintoreros y laborantes de la seda, o Santa Leocadia y la Magdalena. Incluso alguno tuvo casa en san Nicolás, más en concreto un maestro del arte de la seda, o fijaban su residencia en la Alcaicería; ${ }^{108}$ dicho de otra manera, el núcleo del comercio minorista donde tendrían asegurada la presencia de una variada clientela. Es inexplicable la presencia en los poderes de dos labradores, Alonso de Murcia y Baltasar de Molina, por estar uno alistado en Torrijos y el otro en Bargas. ${ }^{109}$

Cuadro V. Domicilio de los moriscos clientes del escribano Hurtado ${ }^{110}$

\begin{tabular}{|l|r|l|r|}
\hline Parroquia & Poderdantes & Parroquia & Poderdantes \\
\hline $\begin{array}{l}\text { Capilla } \\
\text { de S. Pedro }\end{array}$ & 1 & S. Miguel & 7 \\
\hline Magdalena & 2 & S. Nicolás & 13 \\
\hline S. Justo & 6 & S. Román & 2 \\
\hline S. Isidoro & 161 & S. Salvador & 33 \\
\hline S. Juan Bautista & 6 & Sto. Tomé & 134 \\
\hline Sta. Leocadia & 3 & Santiago & 14 \\
\hline San Lorenzo & 11 & No indican & 2 \\
\hline San Martín & 6 & Bargas-Torrijos & \\
\hline
\end{tabular}

Los talleres de los fabricantes de armas abundaban en la puerta de la Herrería y plaza de Zocodover, dos espacios intramuros, donde convivían las tiendas de los cuchilleros cristianos y las de los moriscos, autorizados estos últimos para fabricar

107 Las colaciones parroquiales fueron veintiuna durante los siglos XVI y XVII, más seis mozárabes sin jurisdicción territorial precisa. Porres Martin-Cleto, J. y Martz, L. 1974. Toledo y los toledanos en 156: 135-140. Toledo: IPIET.

${ }^{108}$ En Ávila no pudieron establecerse en el centro urbano, Tapia, S. de. 1991. La comunidad morisca de Ávila. 58 y ss. Salamanca: Universidad. En Ciudad Real preferían las parroquias de Santa María, San Pedro y Santiago, Moreno Díaz, F.J. 2009: 166.

109 Tenían prohibido salir de los lugares donde estaban alistados, si bien hubo cierta laxitud en los reagrupamientos familiares, aparte de migrar con cierta facilidad si no había trabajo en el lugar de residencia. Un caso al respecto es el de Hernando de Alama, oficial de tintorero de seda, alistado en Segovia, que pidió venir a Toledo para sobrevivir con mayor comodidad. AMT. Moriscos, caja 1686.

${ }^{110}$ AHPT. Protocolo, 2208, f. 776 y ss., año 1589, escribano Blas Hurtado. 
armas igual que las de sus convecinos. Una cohabitación pacífica hasta el punto de tener a su servicio a oficiales moriscos. Queda, por último, situar el domicilio de los vendedores menos prósperos, aquellos que colocaron diariamente sus puestos en la plaza de Zocodover y mantuvieron su morada en los distritos de Santiago y San Isidoro. ${ }^{111}$

\section{CONCLUSIONES}

Los moriscos avecindados en Toledo, llegados con posterioridad a 1570, han sido estudiados de manera muy selectiva, sin que exista un trabajo general ni conclusivo sobre ellos, más que nada porque reconstruir los acontecimientos sobre los que se conservan pocas evidencias documentales es dificultoso. Tampoco este artículo es definitivo, a pesar del revoltijo de cifras que contiene. Eso sí, su objetivo ha sido revelar la existencia de una documentación, en tal caso los registros de llegada de los expulsados de varias zonas del antiguo reino granadino, con luces y sombras por estar incompleta y formar cuadernillos sin un orden preciso, con el propósito de ampliar el conocimiento de los que quedaron en Toledo.

Los desterrados llegados durante los primeros años de la década de los setenta, cuyo número quedó en un impreciso digito, 6.000, llegaban hasta Toledo y eran agrupados en el lugar de Burguillos durante poco tiempo, para ser remitidos a diferentes puntos geográficos de la Meseta Norte. No todos hicieron tan largo viaje, ya que algunos cientos quedaron en la ciudad y en los pueblos de su jurisdicción. Algunos centenares, unos esclavos y otros tantos que gozaban de libertad, sin distinguir claramente esta última condición, serán confiados por las autoridades a los toledanos para que trabajasen como sirvientes o aprendices en actividades profesionales de diversa índole. Una magnitud numérica mayor fue instalada en corrales y dependencias inadecuadas, situadas en las parroquias suburbanas de Santiago e Isidoro, donde fueron vigilados y ejercieron profesiones muy dispares. Menos de medio millar fueron traslados a los pueblos de la jurisdicción, de los cuales feneció un porcentaje notable Los empadronamientos realizados de forma sistemática permiten estudiar la estructura de sus hogares, profesión y asiento en el núcleo urbano.

Una variación notable se produjo entre los años setenta y noventa, cuando un impreciso número de esos granadinos cambió de residencia dentro del ámbito ciudadano, al igual que cambiaban de actividad profesional. Aquellos que alcanzaron un cierto grado de prosperidad serán los primeros en abandonar las concentraciones de las barriadas extramuros, instalándose en las intramuros como evidencian los poderes, la otra fuente utilizada, donde queda patente el arco de profesiones desempeñadas. Sin ser categórica la afirmación, sí resulta plausible pensar que muchos evolucionaron y aceptaron las medidas de aculturación y todas las mejoras de vida que tenían a su alcance. Algunos interrogantes no están

111 Las residencias aparecen en las listas de los abonos de las igualas de la fruta verde, uvas, especiería y huevos del ejercicio correspondiente al año 1583. Figuran 31 tratantes moriscos, de ellos 9 dijeron tener sus casas en la parroquia de Santiago y despachar sus mercancías en las "tablas" en Zocodover", mientras el resto la ofrecían de forma ambulante y vivían en otras colaciones. AHPT. Protocolos, 1728, f. 158, año 1583, Gonzalo de Herrera. Las mesas de los vendedores de frutas y otros mantenimientos fueron organizadas con precisión por un comisario de la ciudad, regidor o jurado. AMT. Cartas, años 1601, sig. 307, carpeta 6. 
aclarados, entre ellos saber qué pasó con los sometidos a esclavitud pasados unos años de su entrega.

La segunda reflexión tiene estrecha relación con el efecto sobrevenido por la llegada de esa mano de obra en la economía toledana, dado que la percepción de un insignificante salario benefició a los maestros de la protoindustria y a la oligarquía, al servirse de ellos como fuerza laboral a un precio insignificante. No puede probarse tal causa-consecuencia sin evidencias numéricas, pero no es una idea desacertada.

Al hilo de esa cuestión hay que lanzar, aun siendo la respuesta dificultosa de obtener, otro interrogante: ¿por qué no se cumplió el plan de instalar a varios cientos de esos moriscos en los Montes? La dispersión por la zona geográfica no se realizó en la línea prevista por la falta de control que suponía el asentamiento tanto para la autoridad civil como eclesiástica; de ahí que solo unas pocas docenas quedaron instaladas donde era posible su vigilancia. Con los llevados hasta los pueblos de la Sagra hubo otros motivos para el fracaso y su retorno a la ciudad, como la presión demográfica que produjo su llegada, la gravedad de la crisis de subsistencias que durante la década 1580-89 vivieron esos pueblos, además de la actitud xenófoba que adoptaron sus convecinos con ellos. En fin, un cúmulo de adversidades que impidió a los granadinos obtener recursos y alimentos para sobrevivir.

\section{BIBLIOGRAFÍA}

Actas de las II Jornadas de Metodología Aplicada a las Ciencias Históricas. La documentación notarial y las Historia. Santiago: Universidad, 1984.

Amezcua, M. 1994. "Los sínodos postridentinos en la diócesis de Badajoz", Revista de Estudios Extremeños, 2: 357-391.

Andújar Castillo, F. 1992-93: «Del esclavo morisco al berberisco: sobre la esclavitud en Almería en el siglo XVIII». Boletín del Instituto de Estudios Almerienses, 1112:81-101.

Barrios Aguilera, M. 2000. "El destino de los moriscos vencidos", en Historia del Reino de Granada. II La época morisca y la repoblación (1502-1630). Granada: Universidad.

Benítez Sánchez-Blanco, R. 1999. "La política de Felipe II ante la minoría morisca», en Belenguer Cebriá, E. Felipe II y el Mediterráneo. Los grupos sociales. Madrid: SECC.

Beauvalet Boutouyrie, S. Gourdon, V. Ruggiu, F. J. (dir.). 2004. Liens sociaux et actes notariés dans le monde urbain en France et en Europe. Paris: P. Universitaire Paris-Sorbonne.

Boeglin, M. 2007. «Entre la resistencia y la política de asimilación y la fabulación: el "levantamiento" de los moriscos andaluces de 1580». Historia, Instituciones y Documentos, 34: 29-55.

Bunes Ibarra, M. A. 1983, Los moriscos en el pensamiento histórico: historiografía de un grupo marginado. Madrid: Cátedra.

Candau Chacón, M. L. 1998, Moriscos en el espejo del tiempo. Problemas históricos e historiográficos. Huelva: Universidad

Caro Baroja, J. 1976. Los moriscos del reino de Granada. Ensayo de historia social. Madrid: Istmo.

Carrasco, R. 2009. Deportados en nombre de Dios. Barcelona: Destino. 
Contreras, J. 1996. "Métodos y fuentes: el historiador y sus documentos». La investigación en las fuentes documentales de los Archivos. Guadalajara: Cuadernos de Archivos y Bibliotecas de Castilla-La Mancha.

Cortés López, J. L. 1989. La esclavitud negra en la España peninsular. Salamanca: Universidad.

Cortés Peña, A. L. 1995. «Mudéjares y moriscos granadinos, una visión dialéctica tolerancia-intolerancia», en Barrios Aguilera M. y Vincent, B. Granada 14921992. Del reino de Granada al futuro del Mundo Mediterráneo. Granada: Universidad.

Cortés Peña, A. L. 1999. "Una consecuencia del exilio: los moriscos granadinos en Sevilla», en E. Belenguer Cebriá, E. (coord.). Felipe II y el Mediterráneo. Los grupos sociales. Madrid: SECC.

Dadson, T. J. 2007. Los moriscos de Villarubia de los Ojos (siglos XV-XVIII). Historia de una minoría asimilada, expulsada y reintegrada. Madrid-Frankfurt am Main, Iberoamericana-Vervuert.

Darton, R. 2003. El coloquio de los lectores. México: FCE.

Dedieu, J. P. 1983. "Les Morisques de Daimiel et I'Inquisition (1502-1526)», Les Morisques et leur temps. París : CNRC.

Dedieu, J. P. 1984. "Morisques et vieux chrétiens à Daimiel au XVlème siècle», en Temimi, A. Religion, Identité et Sources Documentaires sur les Morisques Andalous. Tunis: P.I.S.D.

Dedieu. J. P. y García Arenal. M. 1990. «Les tribunaux de Nouvelle Castille», en L. Caidallac (dir.), Les Morisques et I'Inquisition. París: Publisud

Domínguez Ortíz, A. y Vincent, B. 1978. Historia de los moriscos. Vida y tragedia de una minoría. Madrid: Revista de Occidente.

Fernández Chaves, M. F. y Pérez García, R. M. 2011. «Notas sobre la destrucción de las comunidades moriscas malagueñas y su reconstrucción en la campiña sevillana, 1569-1610». Áreas, Revista Internacional de Ciencias Sociales, 30: 121-139.

García-Arenal Rodríguez, M. 1975. Los moriscos, Madrid: Editora Nacional.

García López, A. 2009. Señores, seda y marginación. La comunidad morisca de Pastrana. Guadalajara: Aache Ediciones.

García Pedraza, A. 1995. «El otro morisco: algunas reflexiones sobre el estudio de la religiosidad morisca a través de los protocolos», Sharq Al-Andalus, 12: 223234.

García Pedraza, A. 2002. Actitudes ante la muerte en la Granada del siglo XVI: los moriscos que quisieron salvarse. Granada: Universidad.

Gómez Sánchez, D. 1998. La muerte edificada: el impulso centrífugo de los cementerios de la ciudad de Cuenca. Cuenca: Universidad.

Gómez Vozmediano, M. F. 2000. Mudéjares y moriscos en el campo de Calatrava. Ciudad Real: Diputación.

Hernández Bermejo, M. A., Sánchez Rubio R. y Testón Núñez, I. 1995. «Los moriscos de Extremadura», Studia Histórica, Historia Moderna, 13: 89-118.

Hurtado de Mendoza, D. 1842, Guerra de Granada hecha por el rey D. Felipe II. Barcelona: Imprenta Juan Oliveres.

Hurtado de Toledo, L. 1951-63. «Memorial de algunas cosas notables que tiene la Imperial ciudad de Toledo», en Paz, R. y Viñas, C. (trans.), Relaciones histórico geográficas de los pueblos de España. III. Madrid: CSIC. 
Kagan, R. L. 1994. "Contando vecinos: el censo toledano de 1569», Studia Historica. Historia Moderna, XII: 116-135.

Laffont, J. L. 1991. «Un enjeu pour l'exploitation des actes notariés: la représentativité de l'acte et de la pratique notariale», en Problèmes et méthodes d'analyse historique de l'activité notarié (XVe-XIXe siècles).Toulouse: P. Universitaires du Mirail.

Lapeyre, H. 1986. Geografía de la España morisca. Valencia: Universidad.

López, A. 1995. «Moriscos andalusíes en Pastrana. Las quejas de una minoría marginada de moriscos, con noticias sobre su paralelismo en el reino de Granada», Sharq al-Andalus, 12: 163-177.

Le Goff, J. 1989. «Documento/Monumento», Irargi. Revista de Archivística, II: 102131.

Magán J. M. y Sánchez González, R. 1993. Moriscos granadinos en la Sagra de Toledo, 1570-1610. Toledo: Caja de Ahorros.

Martínez Gil, F. 1993. Actitudes ante la muerte en la España de los Austrias. Madrid: Siglo XXI.

Martínez Millán, J. Felipe II (1527-1598), Europa y la Monarquía Católica. Madrid: Parteluz.

Martz, L. 1983. Poverty and welfare in Habsburg Spain. Cambridge: UP.

Martz, L. 1995. "Los toledanos y el reino de Granada de 1492 a la década de 1560», en J. Elliot, R. Kagan y G. Parker. 2001. España, Europa y el mundo atlántico. Madrid: Marcial Pons.

Moreno Díaz del Campo, F. J. 2004. «El discurrir cotidiano o la convivencia frustrada: los moriscos granadinos en el campo de Montiel», Cuadernos de Estudios Manchegos, 28: 93-142.

Moreno Diaz, F. J. 2009. Los moriscos de la Mancha: sociedad, economía y modos de vida de una minoría. Madrid: CSIC.

Pareja Pareja, F. A. 1997, "Los matrimonios mixtos: una estrategia usada por el poder en el proceso de aculturación cristiana", Qurtuba, Estudios Andalusíes, 2:164-173

Pedraza, E. 1985. Población morisca en Toledo en la segunda mitad del siglo XVI. Toledo (inédito).

Peñafiel Ramón, A. 1991. Amos y esclavos en la Murcia del Setecientos. Murcia: R. A. Alfonso X el Sabio.

Porres Martin-Cleto, J. y Martz, L. 1974. Toledo y los toledanos en 1561.Toledo: IPIET.

Prieto Bernabé, J. M. 1987. «Aproximación a las características antropológicas de la minoría morisca asentada en Pastrana en el último tercio del siglo XVI», Wad-al-Hayara, 14: 355-362.

Rodríguez de Gracia, H. 1981. "Un censo de moriscos de finales del siglo XVI». Toletvm, XI: 521-542.

Quesada Morillas, Y. 2008. "Los moriscos del reino de Granada: su expulsión y el Consejo de Población», Revista Electrónica de la Facultad de Derecho de la Universidad de Granada.

Sáez, R. 1984. "Los moriscos en el arzobispado de Toledo a finales del siglo XVI» Cuadernos de Historia, 3: 161-172.

Sánchez Ramos, V. 2009. «Importancia historiográfica de los moriscos granadinos», Anuario de Historia de la Iglesia, 18:325-346 
Sánchez Ramos, V. 2000. «La guerra de la Alpujarra, 1568-1570», en Barrios, M. y Peinado, R. (eds.), Historia del Reino de Granada, II: 502-542. Granada: Universidad.

Sánchez Romeralo, J. 1984. "El Conde de Orgaz, protector de los moriscos», La España medieval, IV: II, 900-916.

Santamaría Conde, A. 1981. «Albacete y los moriscos en el siglo XVI: dos expediciones de moriscos de paz», Al-Basit, IX: 39-48.

Santamaría Conde, A. 1984. «Albacete y la deportación general de los moriscos granadinos», Actas I Congreso de Historia de Albacete, Albacete: Instituto de Estudios Albacetenses.

Tapia, S. de, 1990, «Fiscalidad y actividades económicas de los mudéjares de Ávila en el siglo XV». V Simposio Internacional de Mudejarismo, Teruel: Instituto de Estudios Turolenses.

Tapia, S. de, 1991. La comunidad morisca de Ávila. Salamanca: Universidad.

Tapia, S. de, 1994. "Una minoría urbana mal conocida: los moriscos "convertidos" en Castilla la Vieja», en J. Hinojosa y J. Pradells Nadal (eds.), 1490: en el umbral de la Modernidad. El Mediterráneo europeo y las ciudades en el tránsito de los siglos XV-XVI: 447-473. Valencia, Generalitat.

Vincent, B. 1970. "L'expulsion des morisques du Royaume de Grenade et leur répartition en Castille (1570-1571)», Mélanges de la Casa de Velázquez, 6: 211-246.

Vincent, B. 1971. "Combien de Morisques ont été expulsés du royaume de Grenade?», Mélanges de la Casa de Velázquez, 7: 187-222.

Vincent, B. 1985. Andalucía en la Edad Moderna: economía y sociedad. Granada: Diputación.

Vincent, B. 1996. "La disidencia morisca», Disidentes, heterodoxos y marginados en la Historia. Salamanca: Universidad.

Vincent, B. 1998. "¿Qué aspecto físico tenían los moriscos», /l Coloquios de Historia de Andalucía. Córdoba: C.A.M.P de Córdoba.

Zamorano Rodríguez, M. L. 1997. El hospital de San Juan Bautista de Toledo durante el siglo XVI. Toledo: Diputación. 